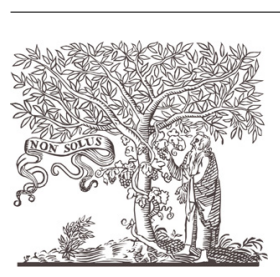

\title{
Behavioral addictions in bipolar disorders: A systematic review
}

\author{
C Varo ${ }^{a}$, A Murru ${ }^{a, * *}$, E Salagre ${ }^{a}$, E Jiménez ${ }^{a}$, B Solé ${ }^{a}$, \\ L Montejo $^{a}$, AF Carvalho ${ }^{\text {b,c }}$, B Stubbs ${ }^{\text {d,e }}$, I Grande ${ }^{a}$, \\ A Martínez-Arán ${ }^{a}$, E Vieta ${ }^{a, *}$, M Reinares $^{a}$
}

\author{
${ }^{a}$ Bipolar Disorders and Depressive Unit, Hospital Clinic, Institute of Neurosciences, University of \\ Barcelona, IDIBAPS, CIBERSAM, Barcelona, Catalonia, Spain \\ ${ }^{\mathrm{b}}$ Department of Psychiatry, University of Toronto, Toronto, ON, Canada \\ 'Centre for Addiction and Mental Health (CAMH), Toronto, ON, Canada \\ d Physiotherapy Department, South London and Maudsley NHS Foundation Trust, Denmark Hill, London \\ SE5 8AZ, United Kingdom \\ 'Department of Psychological Medicine, Institute of Psychiatry, Psychology and Neuroscience, King's \\ College London, De Crespigny Park, London, Box SE5 8AF, United Kingdom
}

Received 17 July 2018; received in revised form 18 September 2018; accepted 23 October 2018

Available online $x x x$

\section{KEYWORDS \\ Bipolar disorder; Behavioral addictions; Comorbidity; Prevalence; Treatment}

\begin{abstract}
Clinical and epidemiological research suggests that behavioral addictions (BA) are associated with a wide range of psychiatric disorders. However, the relationship between BA and bipolar disorders (BD) has not been thoroughly explored. The aim of this systematic review was to critically summarize and evaluate the current available evidence regarding a possible association between BA and BD. A systematic review of major electronic databases according to PRISMA guidelines was conducted from inception to 31st December 2017. We sought quantitative studies data concerning prevalence of comorbidity, features and treatment related to BA-BD comorbidity. Data were narratively synthesized. Of the 1250 studies returned from the search, a total of 28 articles were included in this review. BA may be overrepresented in BD samples, and the other way around. Pathological gambling and kleptomania were the most prevalent conditions followed by compulsive buying, compulsive sexual behavior and internet addiction. BA was also associated with other mood disorders, anxiety disorders and substance use disorder. BD-BA comorbidity was related with more severe course of illness. Studies on treatment strategies for BD-BA comorbidity are rather limited; only one randomized controlled
\end{abstract}

\footnotetext{
* Corresponding author.

E-mail addresses: amurru@clinic.ub.es (A. Murru), EVIETA@clinic.cat (E. Vieta).

**Co-Corresponding author: Bipolar Disorders and Depressive Unit, Clinical Institute of Neurosciences, Hospital Clinic, Villarroel 170,08036 Barcelona (Spain).
} 
trial that fulfilled inclusion criteria was identified. Methodological heterogeneity in terms of design and results among studies was found. BD-BA commonly co-occurs although there is a need for rigorous studies. Routine screening and adequate assessment may be helpful in BD patients to identify individuals at risk for BA and to effectively manage the complex consequences associated with BA-BD comorbidity.

(C) 2018 Elsevier B.V. and ECNP. All rights reserved.

\section{Introduction}

Bipolar disorder (BD) is a severe and chronic condition which clinical manifestations may encompass different symptom dimensions beyond the core expression related to alterations in mood and energy. For instance, BD patients can present high impulsivity (Jimenez et al., 2016), and increased comorbidity with other psychiatric disorders (including anxiety disorders, substance use disorders (SUD), attention-deficit/hyperactivity disorder and personality disorders (PD)), which can make diagnosis and management of BD more difficult; this comorbidity is also associated with poorer outcomes (Grande et al., 2016; Vieta et al., 2018a). Comorbidity with SUD is associated with a worse course of bipolar illness, as it may trigger illness onset (Swann et al., 2004), increase the risk of suicidal behavior (Ostergaard et al., 2017), relate to functional impairment (Cardoso et al., 2015), poor treatment adherence (Murru et al., 2013), and a lower quality of life (Singh et al., 2005).

Over the last decade, the concept of addiction has been stretched beyond substances to include behavioral addictions (BA). There is some evidence that BA and SUD could share common biological and behavioral characteristics (Grant et al., 2010). BA are characterized by the repetitive occurrence of impulsive and uncontrolled acts that can turn into addictive behaviors over time, causing psychological, social and working problems, sometimes with legal and economic consequences (Lejoyeux et al., 2000). Similar to SUD, BA affects the neural circuitry of the brain's reward system. Patients with BA report an urge or craving state prior to initiating the behavior and dysphoric state while abstaining from the behaviors as do patients with SUD. However, unlike substance withdrawal, there are no reports of physiological prominent or medically serious withdrawal states from BA (Grant et al., 2010). The DSM-5 (American Psychiatric Association, 2013) represents a conceptual change with the inclusion of pathological gambling (PG) under the term "gambling disorder" within the category of addictions, thus defining and recognizing BA (Demetrovics and Griffiths, 2012). Also, in DSM-5, criteria for “Internet gaming disorder" have been proposed into section III ("emerging measures and models") as an area that required further research before possible inclusion in future editions of the DSM. In previous versions of DSM, PG was included under the umbrella of impulse control disorders (ICD), a separate category from SUD. In this sense, kleptomania has also been hypothesized as having similarities to SUD but it is still classified as ICD. Although not included as formal diagnoses in current psychiatric diagnostic systems, additional behaviors such as compulsive buying (Black, 2007), internet addiction (IA)(Ko et al., 2012), video/computer game addiction (Porter et al., 2010), compulsive sexual behavior, (Goodman, 1992), food addiction, compulsive buying, work addiction, tanning addiction or physical exercise addiction (Ascher and Levounis, 2015) could be also considered as BA. Yet, not every ICD, or impulsivity-related disorders have been included within the emerging concept of BA. For example, it remains unclear whether trichotillomania, skin-picking disorder, pyromania or intermittent explosive disorder could be conceived as BA. Therefore, the current classification and diagnosis of BA are to date a matter of ongoing debate (Ascher and Levounis, 2015) yet the evidence is clear that BA are associated with worse clinical outcomes and quality of life (Medeiros et al., 2017).

Previous clinical and epidemiological studies suggest that $\mathrm{BA}$ are related to a wide range of psychiatric disorders (Chamberlain et al., 2016; Grant et al., 2010). BA has been viewed as an attempt to self-medicate or escape negative mood states (Goldstein and Bukstein, 2010). The co-occurrence of BA-BD ( $\mathrm{Di}$ et al., 2010; Sapir et al., 2013) could be explained through either BA may trigger or predispose to $\mathrm{BD}$ or $\mathrm{BD}$ may predispose to $B A$ through increased sensitivity to rewarding stimuli or through self-treatment. Also, BA and BD could share common features such as the emotional instability and impulsivity. However, comorbidity rates, features and treatment related to the association between BA and BD have not been thoroughly studied and, to the best of our knowledge, no systematic review has explored this issue. Thus, a better understanding of the possible associations between BA and BD at epidemiological, phenomenological and mechanistic levels may provide clinical insights for the recognition, management, and understanding of complex patients exhibiting both bipolar spectrum disorders and BA.

Comorbid prevalence rates can be expressed in two ways: the prevalence of psychiatric disorders, especially $B D$ with a comorbid BA and the prevalence of BA with a comorbid BD. Hence, the aim of this systematic review was to critically consider and summarize current available evidence regarding a possible association between BA and BD. Specifically we focused on: (1) Prevalence of comorbid BD in subjects with BA, and associated features, (2) prevalence of comorbid $B A$ in subjects with $B D$, and associated features and, finally, (3) specific treatments for comorbid presentations of $\mathrm{BD}$ and BA.

\section{Experimental procedures}

This systematic review was performed according to the Preferred Reporting Items for Systematic Reviews and Meta-Analyses (PRISMA) guideline recommendations (Moher et al., 2009).

To identify studies for this review, a systematic search was performed using MEDLINE/PubMed/Index Medicus, 
Cochrane Library and Psycinfo of all articles published up to December 31st 2017, cross-checking the obtained references. The systematic search was performed as follows:

MEDLINE/PubMed/Index Medicus string: keywords ("psychiatric disorder" OR "mood disorders" OR "bipolar disorder" OR "bipolar affective disorder" OR "manic" OR "mania” OR "bipolar depress*”) AND ("behav* addict*” OR "non-substance-related addiction" OR "impulse control" OR "internet addict*" OR "excessive internet use" OR "pathological internet use" OR "problematic internet use" OR “computer addict*" OR "gambl*” OR "eat addict*” OR "food addict*" OR "sex* addict*" OR "shopping addict*" OR "compulsive buying" OR "compulsive sex behav"” OR "buy* addict*" OR “work addict*" OR "tanning addict*" OR "physical exercise addict*" OR "physical activit* addict*” ). Cochrane library: we used the same search strategy.

Psychinfo: we used the same search strategy.

\section{Eligibility criteria and study selection}

Records were reviewed using the following inclusion criteria: (1) samples of patients diagnosed with $B D$ presenting a comorbid diagnosis of BA, (2) samples of patients with BA presenting a comorbid diagnosis of $B D,(3)$ mixed samples (e.g., mood disorders patients) with separate outcomes for BD patients, (4) studies conducted on adult ( $\geq 18$ years) individuals, (5) case-control and cohort studies, retrospective and prospective, population or register-based, (6) subanalyses or post-hoc analyses considering comorbid BD and BA of wider studies in which the original study did not provide details on $B D$ and $B A$ comorbidity, (7) studies published in English language. The following exclusion criteria were applied: (1) studies concerning addictions in general, but not specifying the type of BA, (2) studies including individuals at high risk for $B D$ with no validated diagnosis (i.e. no standardized diagnostic assessment) and (3) reports not published, uncompleted studies, letters to the editor, opinions or commentaries, reviews, case reports, and short communications.

\section{Data extraction}

Using the PRISMA statement, articles were selected based on title and abstract. Full texts of the potentially eligible studies were independently assessed for eligibility by two blind independent researchers (CV and MR). References identified through other sources were also reviewed to identify further possible studies of interest.

Extracted information included: main BA, first author, year, study design, primary and secondary aim, general sample size (BD patients in a BA sample and vice versa), BA assessment, primary results and secondary results. It was not possible to do a meta-analysis due to heterogeneity in the outcomes/population thus we conducted a narrative synthesis of the available evidence.

\section{Results}

The global search first returned 1250 titles (Fig. 1). We excluded 14 duplicates articles, so that 1236 articles under- went title and abstract examination. Further 1097 articles unrelated to the aim of this review, 55 reviews, 33 case reports, 3 short communications, 4 letters to the editor, 2 commentaries, 1 supplement and 5 studies involving only children/adolescents were excluded. Thirty-six full text articles were assessed for eligibility and 8 full-text articles were excluded (DeCaria et al., 1996; Kafka and Prentky, 1992; Kesebir, 2012; Soberay et al., 2014; Hollander et al., 2005a; Wolfling et al., 2015; Mclntyre et al., 2007; NunesNeto et al., 2018). In the end, 28 full text articles were included in the systematic review (Black and Moyer, 1998; Kausch, 2004; Hodgins et al., 2005; Petry et al., 2005; Dannon et al., 2006; Zimmerman et al., 2006; Kessler et al., 2008; Edens and Rosenheck, 2012; Abdollahnejad et al., 2014; Nower et al., 2015; Raymond et al., 2003; Scanavino et al., 2013; Kim et al., 2016; Bernardi and Pallanti, 2009; Lejoyeux et al., 2002; Presta et al., 2002; Bayle et al., 2003; Dannon et al., 2004; Di et al., 2010; Sapir et al., 2013; Quilty et al., 2011; Quilty et al., 2017; Kawa et al., 2005; Kennedy et al., 2010; Jones et al., 2015; Kesebir et al., 2012; Karakus and Tamam, 2011; Manning et al., 2017).

\section{Prevalence of comorbid BD in subjects with BA, and associated features}

A total of 19 studies were included in this section (Table 1). Among these, 11 studies were on PG (Black and Moyer, 1998; Kausch, 2004; Hodgins et al., 2005; Petry et al., 2005; Dannon et al., 2006; Zimmerman et al., 2006; Kessler et al., 2008; Edens and Rosenheck, 2012; Abdollahnejad et al., 2014; Nower et al., 2015; Manning et al., 2017), 2 on compulsive sexual behavior (Raymond et al., 2003; Scanavino et al., 2013), 2 on IA (Kim et al., 2016; Bernardi and Pallanti, 2009), 1 on ICD (including PG and kleptomania) (Lejoyeux et al., 2000) and 3 on kleptomania (Presta et al., 2002; Bayle et al., 2003; Dannon et al., 2004).

\section{Pathological gambling (PG)}

Across the 11 studies there were 1006 people with BD.

The National Epidemiologic Survey of Alcohol and Related Conditions found that the lifetime prevalence of PG in a sample of 43093 individuals was $0.42 \%$ (Petry et al., 2005). When considering comorbidities, results confirmed high rates of alcohol use disorder (73.2\%), PD (60.8\%), nicotine dependence $(60.4 \%)$, mood disorder $(49.6 \%)$, an anxiety disorder (41.3\%), and any other drug use disorder (38.1\%). Among patients with lifetime prevalence of any mood disorder, $36.9 \%$ presented a lifetime diagnosis of major depressive episode, $22.8 \%$ of manic episodes and $4.6 \%$ of hypomanic episodes.

Data from the United Stated National Comorbidity Survey Replication revealed that in a sample of 9282 individuals, the lifetime prevalence of problem gambling was $2.3 \%$, while the lifetime prevalence of PG was $0.6 \%$ (Kessler et al., 2008). Among patients with PG, $96.3 \%$ of survey respondents also met lifetime criteria for one or more other psychiatric disorders. Concerning BD, the estimated lifetime prevalence of PG among BDII was $2.9 \%$.

A case-control study focusing on all veterans accessing veterans' health mental services $(n=1102846)$ evaluated 


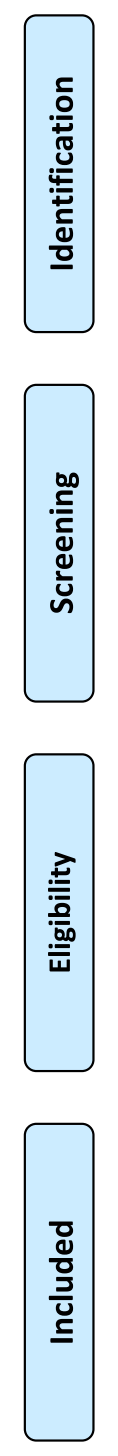

1212 records identified through database searching PubMed/Medline: 1195

Psycinfo: 3

Conchrane: 14 (cross-reference in articles and reviews)

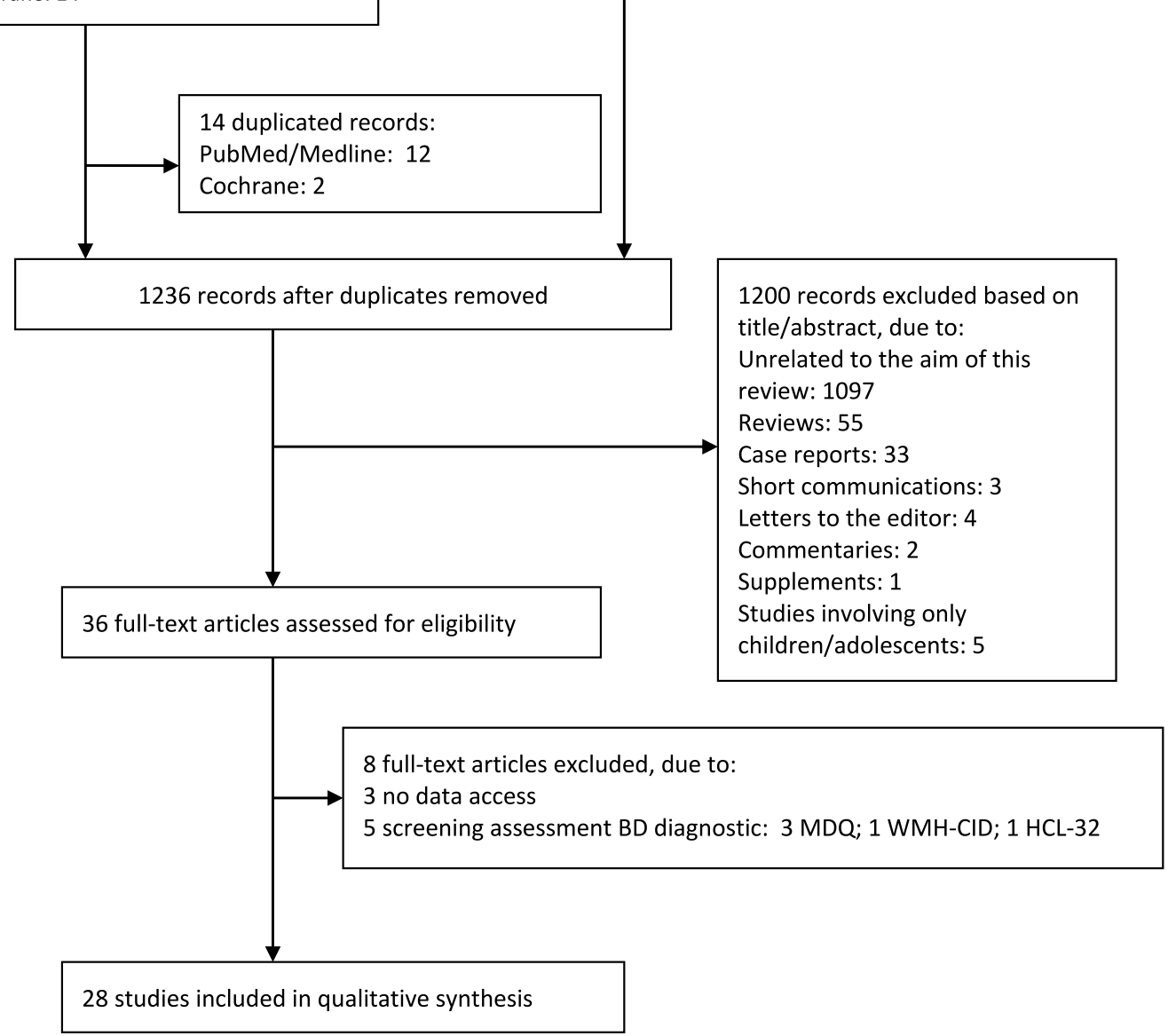

Fig. 1 PRISMA flow-chart of the studies considered and finally selected for review.

rates of PG diagnosis and the comorbidity among PG patients (Edens and Rosenheck, 2012). The results showed that veterans with PG $(n=2,283)$ were lower compared with non-PG $(n=1,100,563)$. The results showed that the prevalence of PG was $0.21 \%$. Among PG cases, $20.5 \%$ met diagnosis for BD $(n=469)$. When PG cases were compared with patients without PG, a significant association was found between PG and alcohol use disorders, followed by BD and PD.

An epidemiologic study that assessed the prevalence of PG and its comorbid psychiatric disorders in a 275 homeless population of United States of America (Nower et al., 2015), revealed that $P G$ patients ( $\geq 1$ symptom) $(n=127,46 \%)$ were 3 -fold more likely than non-PG patients $(n=88,32 \%)$ to meet diagnostic criteria for BD, followed by antisocial PD, post-traumatic stress disorder, any other mental health psychiatric disorder and nicotine use. Also, the results revealed that among PG individuals, 68\% met diagnostic criteria for BD.
The prevalence and diagnostic correlates of PG in psychiatric outpatients was evaluated in a cross-sectional study including 1709 individuals (Zimmerman et al., 2006). Results showed that $2.3 \%(n=40)$ of patients had a lifetime disorder of PG. Patients with PG were 4-fold more frequently diagnosed with a lifetime history of BDI, followed by panic disorder with agoraphobia, alcohol abuse/dependence, and other ICD than non-PG.

In a recent cross-sectional study the prevalence of gambling problems across the risk continuum and its relationship with substance use and specific psychiatric diagnoses among 831 patients was examined (Manning et al., 2017). Results revealed that $6.3 \%(n=53)$ of patients were classified as problem gamblers. Also, the results suggested that drug use, borderline PD, BD, and psychotic disorder were significant predictors of PG.

A cross-sectional study that evaluated the psychiatric comorbidity of 30 PG patients (Black and Moyer, 1998) revealed high rates of any lifetime SUD (64\%), any lifetime 
Table 1 Main studies assessing the prevalence of comorbid BD in subjects with BA and associated features.

\begin{tabular}{|c|c|c|c|c|c|c|c|c|c|}
\hline Main BA & $\begin{array}{l}\text { First Author, } \\
\text { year }\end{array}$ & Study design & $\begin{array}{l}\text { Primary aim(s) of } \\
\text { the study }\end{array}$ & $\begin{array}{l}\text { Secondary } \\
\text { aim(s) of the } \\
\text { study }\end{array}$ & $\begin{array}{l}\text { General sample } \\
\text { size }\end{array}$ & $\mathrm{BD}(\mathrm{n} ; \%)$ & $\begin{array}{l}\mathrm{BA} \\
\text { assessment }\end{array}$ & Primary result(s) & Secondary result(s) \\
\hline \multirow[t]{3}{*}{$\begin{array}{l}\text { Pathological } \\
\text { gambling (PG) }\end{array}$} & $\begin{array}{l}\text { Black \& Moyer } \\
\text { (1998) }\end{array}$ & $\begin{array}{l}\text { Cross- } \\
\text { sectional }\end{array}$ & $\begin{array}{l}\text { To examine } \\
\text { psychiatric } \\
\text { comorbidity and } \\
\text { sociodemo- } \\
\text { graphic features } \\
\text { of subjects with } \\
\text { PG }\end{array}$ & & $\mathrm{n}=30$ & $\begin{array}{l}\text { Current diagnosis } \\
\text { (past } 6 \text { months): } \\
n=5,17 \% . \\
\text { Lifetime } \\
\text { prevalence: } \\
n=6,20 \%\end{array}$ & SOGS & $\begin{array}{l}\text { Prevalence of psychiatric } \\
\text { comorbid disorders: mood } \\
\text { disorders }(60 \%) ; \text { SUD }(64 \%) ; \\
\text { anxiety disorder (40\%); CSB } \\
\text { (17\%); compulsive buying (23\%); } \\
\text { The typical subject was a } \\
\text { 44-year-old white married man } \\
\text { with income of } \$ 34.250, \text { visited } \\
\text { a casino one or more weekly }\end{array}$ & \\
\hline & Kausch (2004) & $\begin{array}{l}\text { Cross- } \\
\text { sectional }\end{array}$ & $\begin{array}{l}\text { To compare } \\
\text { elderly and } \\
\text { younger gamblers } \\
\text { regarding } \\
\text { psychiatric } \\
\text { comorbidity, with } \\
\text { a main focus on } \\
\text { SUD prevalence } \\
\text { and suicidal } \\
\text { ideation and } \\
\text { behavior }\end{array}$ & & $\begin{array}{l}\text { Elderly gamblers: } \\
\mathrm{n}=37 ; \text { young } \\
\text { gamblers: } \mathrm{n}=98\end{array}$ & $\begin{array}{l}\text { Elderly gamblers: } \\
n=1,2.7 \% \text {; } \\
\text { younger } \\
\text { gamblers: } n=8 \text {, } \\
8.2 \%\end{array}$ & DSM-IV & $\begin{array}{l}\text { Any SUD: younger }(72.4 \%) \text { vs. } \\
\text { elderly ( } 33 \%) ; P<0.001 . \\
\text { Any attempts: younger }(42.9 \%) \\
\text { vs. elderly }(22.2 \%) ; P<0.04 \text {. No } \\
\text { significant differences in other } \\
\text { psychiatric comorbidities ( }{ }^{*} B D \text { : } \\
P=0.44)\end{array}$ & \\
\hline & $\begin{array}{l}\text { Hodgins } \\
\text { et al., (2005) }\end{array}$ & $\begin{array}{l}\text { Naturalistic, } \\
12 \text {-month } \\
\text { follow-up } \\
\text { longitudinal } \\
\text { study }\end{array}$ & $\begin{array}{l}\text { To examine the } \\
\text { prevalence and } \\
\text { age of onset of } \\
\text { lifetime and } \\
\text { current alcohol } \\
\text { disorder, SUD and } \\
\text { mood disorder in } \\
\text { PG }\end{array}$ & $\begin{array}{l}\text { To examine } \\
\text { factors } \\
\text { associated } \\
\text { with } \\
\text { abstinence } \\
\text { during } \\
\text { one-year } \\
\text { follow-up }\end{array}$ & $\mathrm{n}=101$ & $\begin{array}{l}\text { Current diagnosis } \\
\text { (past month): BDI } \\
n=0 ; \text {;DII } n=2 \text {, } \\
2 \% \text {. Lifetime } \\
\text { prevalence: BD I } \\
n=4,4 \% ; B D I I \\
n=2,2 \%\end{array}$ & SOGS & 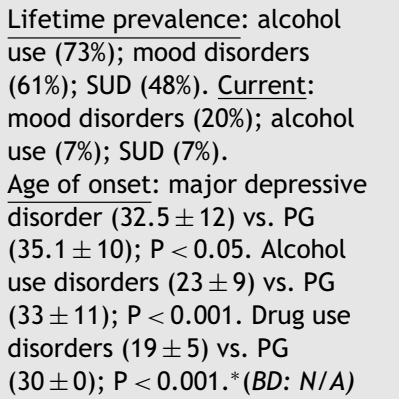 & $\begin{array}{l}\text { Factors associated with } \\
\text { stable abstinence:lifetime } \\
\text { prevalence of mood } \\
\text { disorders }\left({ }^{*} B D: N / A\right) \text {, } \\
\text { current treatment and } \\
\text { current alcohol disorder }\end{array}$ \\
\hline
\end{tabular}




\begin{tabular}{|c|c|c|c|c|c|c|c|c|}
\hline $\begin{array}{l}\text { First Author, } \\
\text { year }\end{array}$ & Study design & $\begin{array}{l}\text { Primary aim(s) of } \\
\text { the study }\end{array}$ & $\begin{array}{l}\text { Secondary } \\
\text { aim(s) of the } \\
\text { study }\end{array}$ & $\begin{array}{l}\text { General sample } \\
\text { size }\end{array}$ & $B D(n ; \%)$ & $\begin{array}{l}\text { BA } \\
\text { assessment }\end{array}$ & Primary result(s) & Secondary result(s) \\
\hline $\begin{array}{l}\text { Petry et al., } \\
\text { (2005) }\end{array}$ & $\begin{array}{l}\text { National Epi- } \\
\text { demiologic, } \\
\text { cross- } \\
\text { sectional }\end{array}$ & $\begin{array}{l}\text { To examine } \\
\text { prevalence and } \\
\text { comorbidity of } \\
\text { PG in a sample of } \\
\text { American } \\
\text { household and } \\
\text { group quarters } \\
\text { residents }\end{array}$ & $\begin{array}{l}\text { To examine } \\
\text { the sex } \\
\text { differences in } \\
\text { comorbid } \\
\text { associations }\end{array}$ & $\mathrm{n}=43093$ & $\begin{array}{l}\text { PG + major } \\
\text { depressive } \\
\text { disorder }(0.95 \%) ; \\
\text { PG + manic } \\
(2.92 \%) ; \\
\text { PG + hypomanic } \\
(0.85 \%) \text { MDD + PG } \\
(36.9 \%) ; \\
\text { manic + PG } \\
\text { (22.80\%); } \\
\text { hypomanic + PG } \\
(4.66 \%)\end{array}$ & AUDADIS-IV & $\begin{array}{l}\text { Non-PG (99.58\%) vs. PG (0.42\%). } \\
\text { Comorbidity prevalence in } \\
\text { subjects with PG: alcohol use } \\
\text { (73.2\%); PD (60.8\%); nicotine } \\
\text { dependence (60.4\%); mood } \\
\text { disorders (49.6\%); anxiety } \\
\text { disorders (41.3\%); SUD (38.1\%) }\end{array}$ & 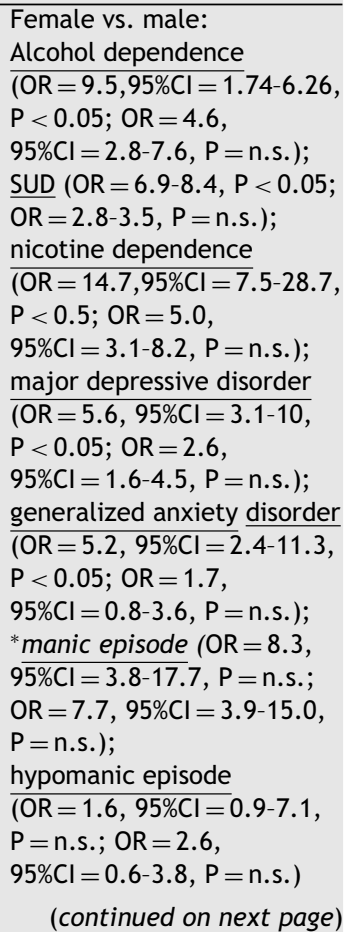 \\
\hline
\end{tabular}




\begin{tabular}{|c|c|c|c|c|c|c|c|c|c|}
\hline Main BA & $\begin{array}{l}\text { First Author, } \\
\text { year }\end{array}$ & Study design & $\begin{array}{l}\text { Primary aim(s) of } \\
\text { the study }\end{array}$ & $\begin{array}{l}\text { Secondary } \\
\text { aim(s) of the } \\
\text { study }\end{array}$ & $\begin{array}{l}\text { General sample } \\
\text { size }\end{array}$ & $\mathrm{BD}(\mathrm{n} ; \%)$ & $\begin{array}{l}\text { BA } \\
\text { assessment }\end{array}$ & Primary result(s) & Secondary result(s) \\
\hline & $\begin{array}{l}\text { Dannon et al., } \\
(2006)\end{array}$ & $\begin{array}{l}\text { Cross- } \\
\text { sectional }\end{array}$ & $\begin{array}{l}\text { To examine the } \\
\text { comorbid } \\
\text { psychiatric } \\
\text { diagnoses in a } \\
\text { cohort of PG and } \\
\text { their } 1 \text { st -degree } \\
\text { relatives }\end{array}$ & & $\begin{array}{l}\text { PG: } n=52 ; 1 s t \\
\text {-degree: } n=93\end{array}$ & $\begin{array}{l}\text { BDI } n=1,2 \% ; \\
\text { BDII } n=1,2 \% ; 1 s t \\
\text {-degree: } n=5 \text {, } \\
5 \%\end{array}$ & SOGS & $\begin{array}{l}\text { Alcohol: patients (19.2\%); } \\
\text { relatives (16.1\%).SUD: patients } \\
(8.0 \%) \text {; relatives (3.2\%). } \\
\text { Problematic gambling: patients } \\
(100 \%) \text {; relatives } \\
(9.7 \%) \text {.Depression: patients } \\
(17.3 \%) \text {; relatives } \\
(18.3 \%) . \text { Anxiety disorders: } \\
\text { patients (13.4\%); relatives } \\
(13.9 \%)\end{array}$ & \\
\hline & $\begin{array}{l}\text { Zimmerman } \\
\text { et al., (2006) }\end{array}$ & $\begin{array}{l}\text { Cross- } \\
\text { sectional }\end{array}$ & $\begin{array}{l}\text { To examine the } \\
\text { prevalence of PG } \\
\text { in a sample of } \\
\text { psychiatric } \\
\text { outpatients }\end{array}$ & $\begin{array}{l}\text { To examine } \\
\text { the } \\
\text { comorbidity } \\
\text { between PG } \\
\text { and other } \\
\text { psychiatric } \\
\text { disorders }\end{array}$ & $n=1709$ & $\begin{array}{l}\text { PG: BDI } n=4 \text {, } \\
\text { 10\%; BDII } n=2 \text {, } \\
\text { 5\% Non-PG: BDI } \\
n=45,2.7 \% \text {; BDII } \\
n=72,4.3 \%\end{array}$ & $\begin{array}{l}\text { SCID }+\mathrm{a} \\
\text { module } \\
\text { DSM-IV PG }\end{array}$ & $\begin{array}{l}\text { Prevalence of PG: } n=40,2.3 \% \text {; } \\
\text { (non-PG: } n=1.669,97.7 \% \text { ) }\end{array}$ & $\begin{array}{l}\text { BDI: PG }(10 \%) \text { vs. Non-PG } \\
(2.7 \%) ; \mathrm{OR}=4 ; \\
95 \% \mathrm{Cl}=1.37-11.74 . \\
\text { Alcohol use: } \mathrm{PG}(62.5 \%) \text { vs. } \\
\text { Non-PG }(40.1 \%) ; \mathrm{OR}=2.5 ; \\
95 \% \mathrm{Cl}=1.30-4.76 . \\
\text { Panic disorder with } \\
\text { agoraphobia: } \mathrm{PG}(42.5 \%) \text { vs. } \\
\text { Non-PG }(18.3 \%) ; \mathrm{OR}=3.3 ; \\
95 \% \mathrm{Cl}=1.74-6.26 . \mathrm{ICD}: \mathrm{PG} \\
(20 \%) \text { vs. Non-PG }(8.2 \%) ; \\
\mathrm{OR}=2.8 ; 95 \% \mathrm{Cl}=1.26-6.19\end{array}$ \\
\hline & $\begin{array}{l}\text { Kessler et al., } \\
(2008)\end{array}$ & $\begin{array}{l}\text { National } \\
\text { comorbidity } \\
\text { survey } \\
\text { replication, } \\
\text { cross- } \\
\text { sectional }\end{array}$ & $\begin{array}{l}\text { To examine the } \\
\text { lifetime gambling } \\
\text { symptoms and PG } \\
\text { along with other } \\
\text { psychiatric } \\
\text { disorders in a } \\
\text { sample of } \\
\text { American survey }\end{array}$ & $\begin{array}{l}\text { To examine } \\
\text { the } \\
\text { associations } \\
\text { between } \\
\text { temporally } \\
\text { 1st disorders } \\
\text { and the } 2 \text { nd } \\
\text { disorders }\end{array}$ & $\begin{array}{l}\mathrm{n}=9,282 \\
\text { individuals }\end{array}$ & $2.9 \%$ & CIDI & $\begin{array}{l}\text { Prevalence gambling }(78.4 \%) \text {; } \\
\text { problem gambling }(2.3 \%) ; \text { PG } \\
(0.6 \%) .96 .3 \% \text { with prevalence } \\
\text { PG meet prevalence for more } \\
\text { disorders }\end{array}$ & $\begin{array}{l}\text { PG onset was predicted by } \\
\text { anxiety mood disorders, ICD } \\
\text { and SUD }\end{array}$ \\
\hline
\end{tabular}




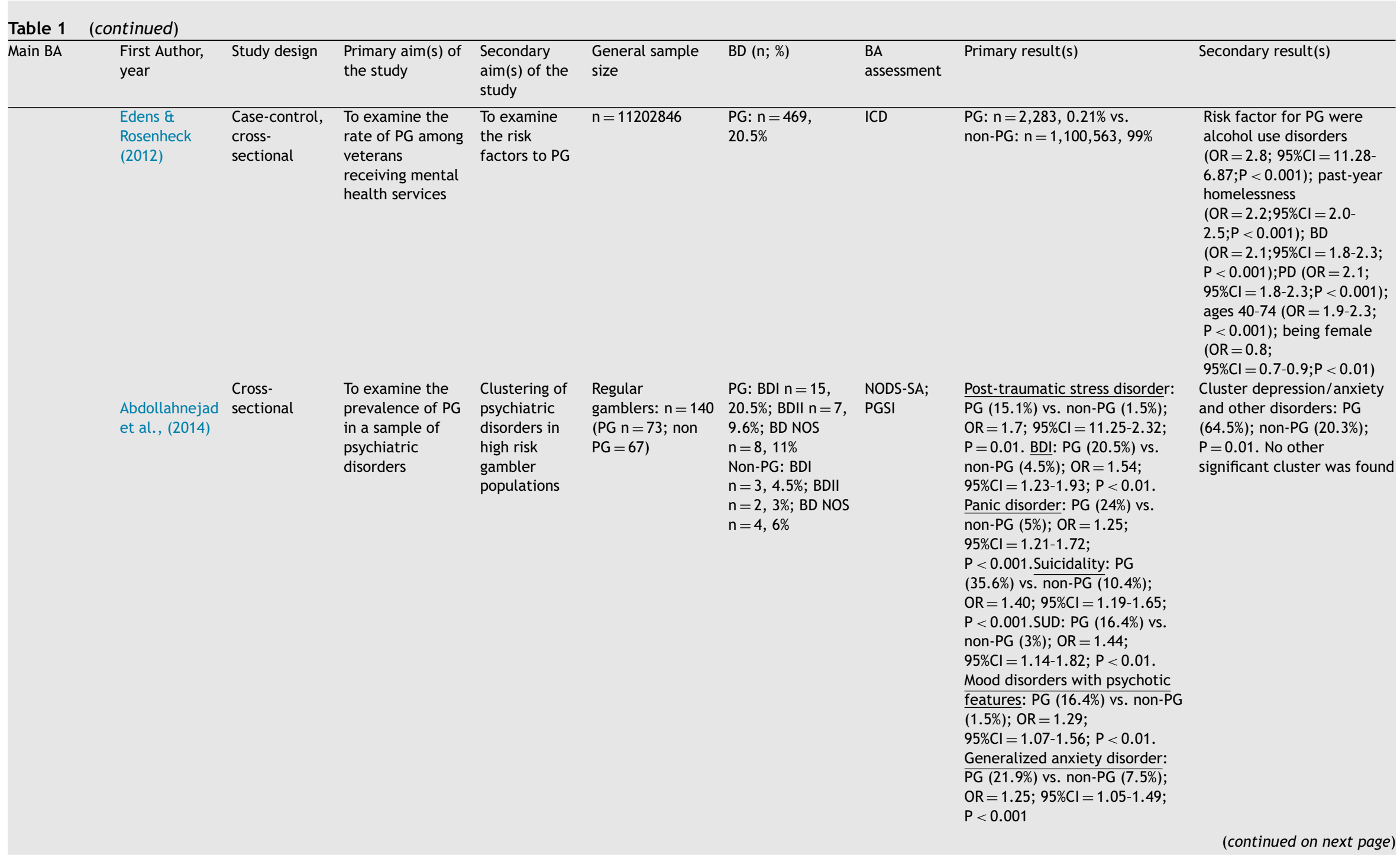




\begin{tabular}{|c|c|c|c|c|c|c|c|c|c|}
\hline Main BA & $\begin{array}{l}\text { First Author, } \\
\text { year }\end{array}$ & Study design & $\begin{array}{l}\text { Primary aim(s) of } \\
\text { the study }\end{array}$ & $\begin{array}{l}\text { Secondary } \\
\text { aim(s) of the } \\
\text { study }\end{array}$ & $\begin{array}{l}\text { General sample } \\
\text { size }\end{array}$ & $\mathrm{BD}(\mathrm{n} ; \%)$ & $\begin{array}{l}\text { BA } \\
\text { assessment }\end{array}$ & Primary result(s) & Secondary result(s) \\
\hline & $\begin{array}{l}\text { Nower et al., } \\
(2015)\end{array}$ & $\begin{array}{l}\text { National Epi- } \\
\text { demiologic, } \\
\text { cross- } \\
\text { sectional }\end{array}$ & $\begin{array}{l}\text { To examine } \\
\text { differences in the } \\
\text { prevalence of } \\
\text { psychiatric } \\
\text { disorders and SUD } \\
\text { by PG severity in } \\
\text { a sample of } \\
\text { American } \\
\text { homeless }\end{array}$ & & $\begin{array}{l}n=275 \\
\text { (non-gamblers: } \\
n=60,21.8 \% \text {; } \\
\text { non-PG: } n=88 \\
32 \% ; \text { PG: } n=127 \text {, } \\
46.2 \% \text { ) }\end{array}$ & $\begin{array}{l}\text { Non-Gamblers: } \\
n=4,16 \% ; \\
\text { Non-PG: } n=7 \text {, } \\
\text { 16\%; PG: } n=17 \text {, } \\
68 \%\end{array}$ & SOGS & 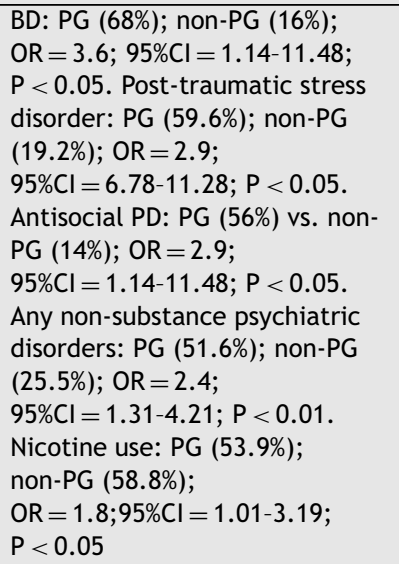 & \\
\hline & $\begin{array}{l}\text { Manning } \\
\text { et al., (2017) }\end{array}$ & $\begin{array}{l}\text { Cross- } \\
\text { sectional }\end{array}$ & $\begin{array}{l}\text { To examine the } \\
\text { prevalence of } \\
\text { gambling } \\
\text { problems and the } \\
\text { relationship with } \\
\text { substance use } \\
\text { and specific } \\
\text { psychiatric }\end{array}$ & & $\mathrm{n}=837$ & $\begin{array}{l}\text { Current diagnosis } \\
\text { (past year): } \\
n=145,17.3 \% \\
\text { Lifetime } \\
\text { prevalence: } \\
n=182,21.7 \%\end{array}$ & PGSI & $\begin{array}{l}\text { Non-problem gamblers }(19.7 \%) \text {, } \\
\text { low-risk gamblers }(7.2 \%) \text {, } \\
\text { moderate-risk gamblers }(8.4 \%) \text {, } \\
\text { problem gamblers }(6.3 \%) \\
\text { Predictors of } \mathrm{PG} \text { : Current } \\
\text { diagnosis drug use }(\mathrm{OR}=4.31 ; \\
95 \% \mathrm{Cl}=1.98-9.37 ; \mathrm{P}<0.001) \text {, } \\
\text { borderline } \mathrm{PD}(\mathrm{OR}=2.59 ; \\
95 \% \mathrm{Cl}=1.13-5.94 ; \mathrm{P}=0.02), \mathrm{BD} \\
(\mathrm{OR}=2.01 ; 95 \% \mathrm{Cl}=1.07-3.38 ; \\
\mathrm{P}=0.03) \text {, and psychotic } \\
\text { disorder }(\mathrm{OR}=1.83 ; \\
95 \% \mathrm{Cl}=1.03-3.25 ; \mathrm{P}=0.04)\end{array}$ & \\
\hline $\begin{array}{l}\text { Compulsive } \\
\text { sexual } \\
\text { behavior } \\
\text { (CSB) }\end{array}$ & $\begin{array}{l}\text { Raymond } \\
\text { et al., } 2003\end{array}$ & $\begin{array}{l}\text { Cross- } \\
\text { sectional }\end{array}$ & $\begin{array}{l}\text { To examine the } \\
\text { prevalence of } \\
\text { psychiatric } \\
\text { disorders in a } \\
\text { sample of } \\
\text { subjects with CSB }\end{array}$ & $\begin{array}{l}\text { To examine } \\
\text { data that } \\
\text { could link CSB } \\
\text { to obsessive- } \\
\text { compulsive } \\
\text { disorder or } \\
\text { the ICD }\end{array}$ & $\mathrm{n}=25$ & $\begin{array}{l}\text { Lifetime } \\
\text { prevalence: } \\
\mathrm{n}=2,8 \%\end{array}$ & $\begin{array}{l}\text { MICQ-S, } \\
\text { CSBI }\end{array}$ & $\begin{array}{l}\text { Anxiety }(96 \%) ; \text { mood disorders } \\
(71 \%) ; \text { SUD }(71 \%)\end{array}$ & $\begin{array}{l}\text { The sample exhibited more } \\
\text { traits of impulsivity than } \\
\text { compulsivity }\end{array}$ \\
\hline
\end{tabular}




\begin{tabular}{|c|c|c|c|c|c|c|c|c|c|}
\hline Main BA & $\begin{array}{l}\text { First Author, } \\
\text { year }\end{array}$ & Study design & $\begin{array}{l}\text { Primary aim(s) of } \\
\text { the study }\end{array}$ & $\begin{array}{l}\text { Secondary } \\
\text { aim(s) of the } \\
\text { study }\end{array}$ & $\begin{array}{l}\text { General sample } \\
\text { size }\end{array}$ & $\mathrm{BD}(\mathrm{n} ; \%)$ & $\begin{array}{l}\text { BA } \\
\text { assessment }\end{array}$ & Primary result(s) & Secondary result(s) \\
\hline & $\begin{array}{l}\text { Scanavino } \\
\text { et al., (2013) }\end{array}$ & $\begin{array}{l}\text { Cross- } \\
\text { sectional }\end{array}$ & $\begin{array}{l}\text { To examine CSB } \\
\text { and comorbid } \\
\text { psychiatric } \\
\text { disorders among } \\
\text { male patients } \\
\text { with CSB }\end{array}$ & & $\mathrm{n}=86$ & $\begin{array}{l}\text { Hypomanic } \\
\text { episodes: } \mathrm{n}=4 \text {, } \\
4.7 \% \text { Manic } \\
\text { episodes: } \mathrm{n}=1 \text {, } \\
1.2 \%\end{array}$ & SCS & $\begin{array}{l}\text { The most common diagnosis } \\
\text { was: anxiety disorders }(46.5 \%) \text {, } \\
\text { mood disorders }(36.1 \%) \text {, SUD } \\
(14.0 \%) \text {, ICD }(12.8 \%)\end{array}$ & \\
\hline $\begin{array}{l}\text { Problematic } \\
\text { internet use } \\
\text { (PIU) }\end{array}$ & $\begin{array}{l}\text { Kim et al., } \\
2016\end{array}$ & $\begin{array}{l}\text { National Epi- } \\
\text { demiologic, } \\
\text { cross- } \\
\text { sectional }\end{array}$ & $\begin{array}{l}\text { To examine the } \\
\text { prevalence, } \\
\text { correlates, and } \\
\text { comorbid of PIU } \\
\text { in a sample of } \\
\text { Korean } \\
\text { individuals }\end{array}$ & & $n=6510$ & $\begin{array}{l}\text { Non- PIU: } n=6 \\
0.2 \% \text { PIU: } n=30 \\
1 \%\end{array}$ & IAT & $\begin{array}{l}\mathrm{PIU}(\mathrm{n}=604) \text { vs. non-PIU } \\
(\mathrm{n}=2968) . \mathrm{PG}: \mathrm{PIU}(1.2 \%) ; \\
\text { non-PIU (0.4\%); OR=5.43; } \\
95 \% \mathrm{Cl}=1.76-16.78 ; \mathrm{P}=0.003 \\
\text { Somatoform disorders: PIU } \\
(1.7 \%) ; \text { non-PIU }(0.8 \%) ; \\
\mathrm{OR}=3.48 ; 95 \% \mathrm{Cl}=1.50-8.08 ; \\
\mathrm{P}=0.004 . \text { Mood disorders: PIU } \\
(10.6 \%) ; \text { non-PIU }(4.6 \%) ; \\
\mathrm{OR}=3.04 ; 95 \% \mathrm{Cl}=2.14-4.32 ; \\
\mathrm{P}<0.001 . \text { Anxiety disorders: } \\
\mathrm{PIU}(9.8 \%) ; \text { non-PIU (5.5\%); } \\
\mathrm{OR}=2.19 ; 95 \% \mathrm{Cl}=1.54-3.09 ; \\
\mathrm{P}<0.001 . \text { Alcohol use } \\
\text { disorders: } \mathrm{PIU}(28.1 \%) ; \text { non-PIU } \\
(16.5 \%) ; \mathrm{OR}=1.59 ; \\
95 \% \mathrm{Cl}=1.27-1.99 ; \\
\mathrm{P}<0.001 .{ }^{*} \mathrm{BD}: \mathrm{OR}=3.12 ; \\
95 \% \mathrm{Cl}=0.88-11.04 ; \mathrm{P}=0.078\end{array}$ & \\
\hline $\begin{array}{l}\text { Internet } \\
\text { addiction (IA) }\end{array}$ & $\begin{array}{l}\text { Bernardi \& } \\
\text { Pallanti } \\
\text { (2009) }\end{array}$ & $\begin{array}{l}\text { Cross- } \\
\text { sectional }\end{array}$ & $\begin{array}{l}\text { To examine } \\
\text { comorbidities } \\
\text { and demographic } \\
\text { features in } \\
\text { patients with IA }\end{array}$ & & $n=15$ & $n=1,7 \%$ & IAS & $\begin{array}{l}\text { Comorbidities: Attention deficit } \\
\text { hyperactivity disorder } \\
\text { symptoms (14\%);generalized } \\
\text { anxiety disorder (15\%); social } \\
\text { anxiety disorder (15\%); } \\
\text { borderline PD (14\%); BDII (7\%); } \\
\text { dysthymia (7\%); } \\
\text { obsessive-compulsive PD (7\%); } \\
\text { avoidant PD (7\%) }\end{array}$ & \\
\hline
\end{tabular}




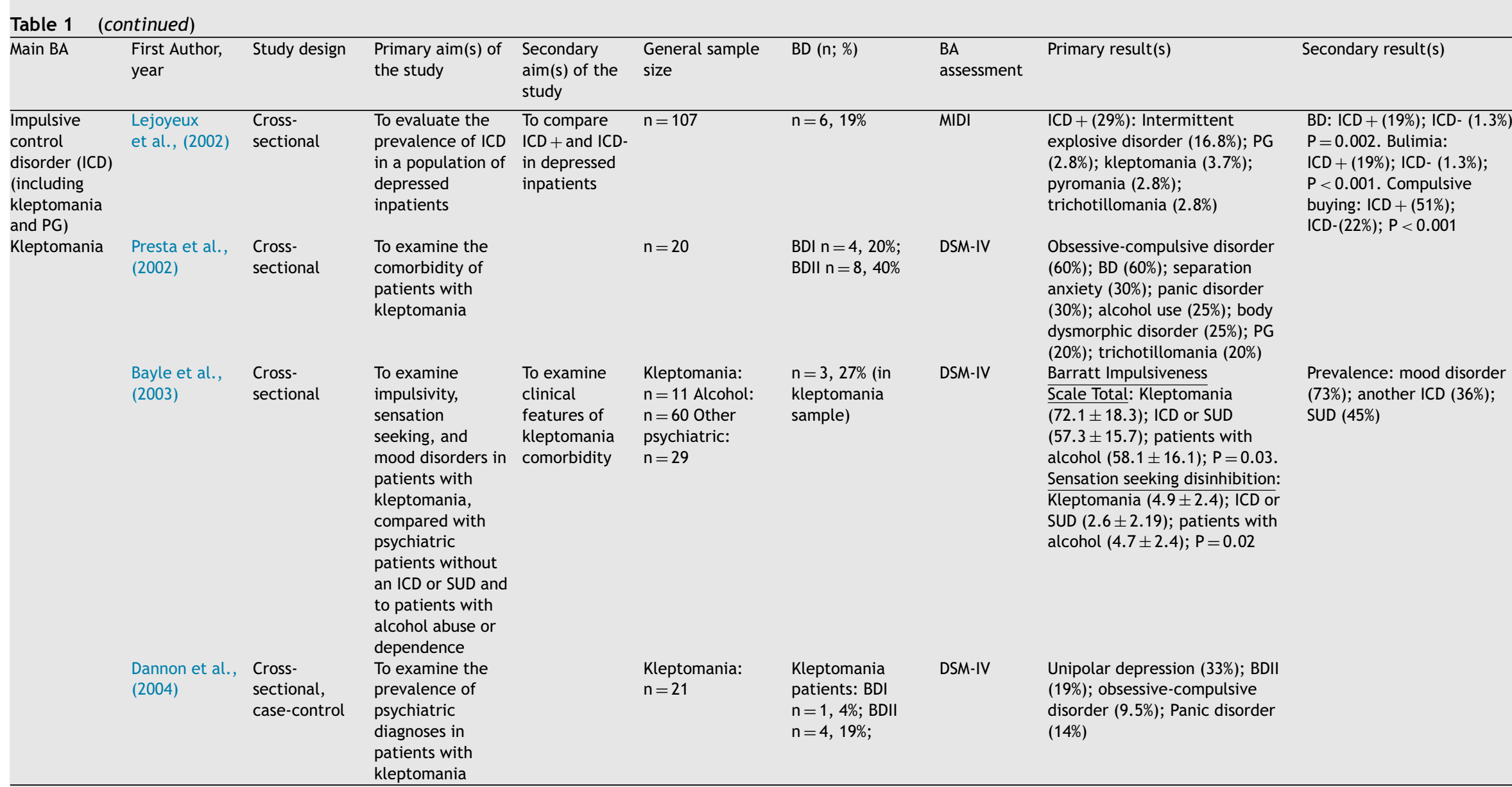

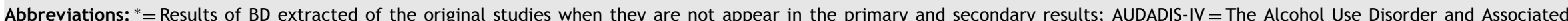

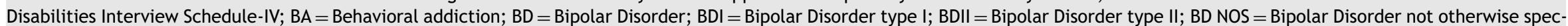

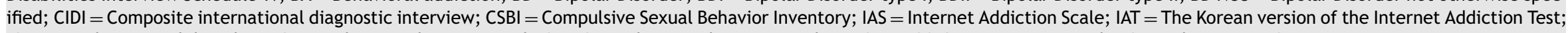

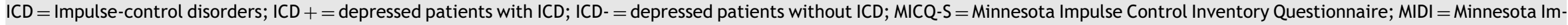
pulsive Disorder Interview; N/A = not applicable; n.p. = not significant differences; OR=odds ratios; PG = Pathological gambling; PD = Personality Disorder; PGSI = Problem Gambling Severity

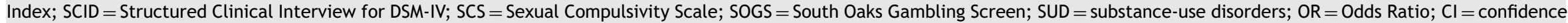
interval 
mood disorder (60\%), any lifetime anxiety disorder (40\%), any lifetime compulsive behavior (43\%) (particularly, compulsive buying (23\%) and compulsive sexual behavior (17\%)). Among those with mood disorders, $20 \%$ reported lifetime BD diagnosis.

A retrospective cross-sectional comparison study between elderly PG patients $(n=37)$ and younger PG patients $(n=98)$ was aimed to investigate lifetime psychiatric comorbidities (Kausch, 2004). No differences were found between elderly and young PG patients. BD diagnosis was present in $2.7 \%$ of elderly gamblers and in $8.2 \%$ of younger gamblers without significant differences between both groups.

A naturalistic sample $(n=101)$ of PG patients was evaluated to determine the association between comorbidity in PG (Hodgins et al., 2005). Results confirmed high rates of lifetime alcohol disorder (73\%), lifetime mood disorders (61\%), and lifetime SUD (48\%). Among those with mood disorders $4 \%$ reported $\mathrm{BDI}$ diagnosis and $2 \% \mathrm{BD}$ II. Additionally, age at onset for mood disorders were equally likely to predate or follow gambling disorders.

A cross-sectional study investigating comorbid psychiatric disorders focused on 52 PG patients and their families (Dannon et al., 2006) reported higher prevalence of alcohol addiction (19\%), unipolar depression (17.3\%) and any anxiety disorder (13.46\%) compared with BD (4\%) among PG patients.

A cross-sectional study that evaluated the association between psychiatric disorders and PG in a sample of 140 regular gamblers (Abdollahnejad et al., 2014) showed that 73 patients of the sample met criteria for PG. Among PG individuals, $91 \%$ had at least one psychiatric diagnosis. Specifically, PG patients presented significantly higher frequency of posttraumatic stress disorder followed by BDI, panic disorder, lifetime suicidal ideation, mood disorder with psychotic features, social phobia and generalized anxiety disorder.

A cross-sectional study assessed the prevalence of ICD (including PG) in 107 patients meeting criteria for major depressive disorder (Lejoyeux et al., 2002). Among 28.9\% depressed patients with ICD, $2.8 \%$ presented PG. BD was significantly more frequent in depressed patients with ICD than in depressed patients without ICD (19 vs.13\%).

\section{Compulsive sexual behavior}

Across the 2 studies there were a total of 8 people with BD.

A cross-sectional study assessed the lifetime prevalence of other psychiatric disorders in 23 patients with compulsive sexual behavior (Raymond et al., 2003). Results confirmed high rates of lifetime any anxiety disorder (96\%), any mood disorder (71\%) and history of SUD (71\%). Among mood disorder, $8 \%$ of the patients with compulsive sexual behavior met diagnostic criteria for BD.

Another cross-sectional study examined compulsive sexual behavior and psychiatric diagnoses in a sample of 86 male patients with compulsive sexual behavior (Scanavino et al., 2013). Among those, 72\% presented any psychiatric diagnosis, especially anxiety disorders (46.5\%), mood disorders (36.1\%), SUD (14\%) and ICD (12.8\%). Among those with mood disorders $5.8 \%$ met diagnostic criteria for, hypomania episodes and $1.2 \%$ for manic episodes. A linear regression indicated that mood disorders predicted higher compulsive sexual behavior scores.

\section{Problematic internet use (PIU)/ internet addiction (IA)}

Across the 2 studies there were a total of 31 people with BD.

A study aimed to investigate the prevalence and psychiatric comorbidities of individuals diagnosed with PIU in a national cohort of 6510 Korean subjects (Kim et al., 2016). The results showed that $9.3 \%$ of the sample met criteria for problematic internet use. Individuals with problematic internet use were more likely to present PG, mood disorders, anxiety disorder and alcohol use disorder than non-problematic internet use individuals. No differences were reported concerning BD prevalence between nonproblematic internet use $(0.2 \%)$ and problematic internet use individuals (1\%).

A cross-sectional study examined psychiatric comorbidities in patients with IA (Bernardi and Pallanti, 2009). IA was found in 15 out of 50 patients. The most prevalent comorbid diagnoses were any anxiety disorders (30\%), any PD (28\%) and attention deficit and hyperactivity disorder (14\%). Regarding mood disorders, $7 \%$ of the patients with diagnosis of IA met diagnostic criteria for BDII.

\section{Kleptomania}

Across the 3 studies there were a total of 24 people with BD.

A cross-sectional study aimed to evaluate the clinical features and psychiatric comorbidities of 20 outpatients with a lifetime diagnosis of kleptomania (Presta et al., 2002). All patients met criteria for other psychiatric disorder, especially mood, anxiety disorders, and any other ICD. Among those with mood disorders, $60 \%$ reported BD. When sociodemographic and clinical features were examined, the results showed that BDI and bulimia were significantly more likely to occur in women with kleptomania than in men.

A cross-sectional study assessed the prevalence of ICD (including kleptomania) in 107 patients meeting criteria for major depressive disorder (Lejoyeux et al., 2002). Among $31(28.9 \%)$ depressed patients with ICD, 4 (3.7\%) presented kleptomania. BD was found in 3 out of 4 (75\%) patients with kleptomania.

A cross-sectional study was performed on the incidence of comorbid psychiatric conditions in a sample of 11 individuals with kleptomania (Bayle et al., 2003). Among those, 73\% had a mood disorder, with $27 \%$ individuals fulfilling criteria for BD.

Another cross-sectional study assessed 21 patients affected by kleptomania and their relatives $(n=57)$ in order to identify possible comorbid psychiatric diagnoses (Dannon et al., 2004). Results showed that 33\% of patients with kleptomania presented unipolar depression, 19\% BDII, 4\% BDI, $14 \%$ panic disorder and $9.5 \%$ obsessive-compulsive disorder.

\section{Prevalence of comorbid BA in subjects with BD, and associated features}

A total of 9 studies were included in this section (Table 2). Among these, 2 studies were on BA (Di et al., 2010; Sapir et al., 2013), 5 on PG (Quilty et al., 2011; Quilty et al., 2017; Kawa et al., 2005; Kennedy et al., 2010; Jones et al., 2015), 1 on compulsive buying (Kesebir et al., 2012) and 1 on ICD (Karakus and Tamam, 2011). 
Table 2 Main studies assessing the prevalence of comorbid BA in subjects with BD and associated features.

\begin{tabular}{|c|c|c|c|c|c|c|c|c|c|}
\hline Main BA & $\begin{array}{l}\text { First Author, } \\
\text { year }\end{array}$ & Study design & $\begin{array}{l}\text { Primary aim(s) } \\
\text { of the study }\end{array}$ & $\begin{array}{l}\text { Secondary aim(s) } \\
\text { of the study }\end{array}$ & $\begin{array}{l}\text { BA assess- } \\
\text { ment }\end{array}$ & $\begin{array}{l}\text { Criteria for } \\
\text { euthymia }\end{array}$ & $\begin{array}{l}\text { General } \\
\text { sample size }\end{array}$ & Primary result(s) & Secondary result(s) \\
\hline \multirow[t]{2}{*}{$\begin{array}{l}\text { Behavioral } \\
\text { Addictions } \\
\text { (BA) }\end{array}$} & $\begin{array}{l}\text { Di et al., } \\
(2010)\end{array}$ & $\begin{array}{l}\text { Cross- } \\
\text { sectional } \\
\text { Case-control }\end{array}$ & $\begin{array}{l}\text { To examine the } \\
\text { prevalence of } \\
\mathrm{BA} \text { in a sample } \\
\text { of } \mathrm{BD}\end{array}$ & $\begin{array}{l}\text { To compare } \\
\text { BA + /BA- for so- } \\
\text { ciodemographic, } \\
\text { clinical } \\
\text { variables, } \\
\text { impulsivity and } \\
\text { temperamental } \\
\text { dimensions }\end{array}$ & $\begin{array}{l}\text { SOGS; } \\
\text { CBS; SAST; } \\
\text { WART; EAI; } \\
\text { IAS }\end{array}$ & $\begin{array}{l}\text { At least two } \\
\text { months: } \\
\text { HDRS }<8 \\
\text { YMRS }<6 \\
\text { CGI }=3-4\end{array}$ & $\begin{array}{l}\text { BDI: } n=71 \\
45 \% ; \text { BDII: } \\
n=44,28 \% \\
\text { Cy- } \\
\text { clothymic: } \\
n=43,27 \% \\
\text { HC: } n=200\end{array}$ & $\begin{array}{l}\mathrm{BA}+: n=52 ; \mathrm{BA}-: \mathrm{n}=106 . \\
\mathrm{PG}: \mathrm{BD}(7 \%) \text { vs. } \mathrm{HC}(1 \%) ; \\
\mathrm{P}<0.001 . \mathrm{CB}: \mathrm{BD}(17 \%) \text { vs. } \\
\mathrm{HC}(6 \%) ; \mathrm{P}=0.042 . \\
\text { Sexual addiction: } \mathrm{BD}(3 \%) \text { vs. } \\
\mathrm{HC}(2 \%) ; \mathrm{P}<0.001 . \\
\text { Work addiction: } \mathrm{BD}(13 \%) \text { vs. } \\
\mathrm{HC}(4 \%) ; \mathrm{P}=0.005\end{array}$ & $\begin{array}{l}B A+: \text { higher unemployed } \\
(P=0.021) \text {; axis II comorbidity } \\
(P=0.023) \text {; higher impulsivity } \\
\text { level }(P=0.007) \text { than } \\
B A-B A+: \text { lower scores in } \\
\text { Self-directness }(P=0.007) ; \\
\text { cooperativeness }(P=0.014) \\
\text { than } B A-\end{array}$ \\
\hline & $\begin{array}{l}\text { Sapir et al., } \\
\text { (2013) }\end{array}$ & $\begin{array}{l}\text { Cross- } \\
\text { sectional } \\
\text { Case-control }\end{array}$ & $\begin{array}{l}\text { To examine the } \\
\text { interrelation- } \\
\text { ship between } \\
\mathrm{BD} \text { and } \mathrm{BA} \\
\text { (harmful and } \\
\text { benign } \\
\text { addictions), } \\
\text { and } \\
\text { temperamental } \\
\text { traits }\end{array}$ & & $\begin{array}{l}\text { Behavioral } \\
\text { Addiction } \\
\text { Scale }\end{array}$ & $\begin{array}{l}\text { Consensus } \\
\text { between the } \\
\text { two treating } \\
\text { physicians }\end{array}$ & $\begin{array}{l}\text { BDI: } n=50 \\
\text { HC: } n=50\end{array}$ & $\begin{array}{l}\text { BD: higher scores on music, } \\
\text { shopping and smoking } \\
\text { addictions than } H C \\
(P<0.05) . \text { Harmful } \\
\text { addictions and novelty } \\
\text { seeking: } B D(r=0.33 ; \\
P<0.05) \text { vs. } H C(r=0.32 \text {, } \\
P<0.05) . \text { Harmful addictions } \\
\text { and cooperativeness: BD } \\
(r=-0.42 ; P<0.001) \text { vs. HC } \\
(r=-0.28, P<0.05) . \text { Benign } \\
\text { addictions and } \\
\text { self-transcendence: } \\
B D(r=0.31 ; P<0.05) \text { vs. } \\
H C(r=0.29, P<0.05)\end{array}$ & \\
\hline
\end{tabular}


Table 2 (continued)

\begin{tabular}{|c|c|c|c|c|c|c|c|c|c|}
\hline Main BA & $\begin{array}{l}\text { First Author, } \\
\text { year }\end{array}$ & Study design & $\begin{array}{l}\text { Primary aim(s) } \\
\text { of the study }\end{array}$ & $\begin{array}{l}\text { Secondary aim(s) } \\
\text { of the study }\end{array}$ & $\begin{array}{l}\text { BA assess- } \\
\text { ment }\end{array}$ & $\begin{array}{l}\text { Criteria for } \\
\text { euthymia }\end{array}$ & $\begin{array}{l}\text { General } \\
\text { sample size }\end{array}$ & Primary result(s) & Secondary result(s) \\
\hline \multirow[t]{3}{*}{$\begin{array}{l}\text { Pathological } \\
\text { gambling } \\
\text { (PG) } \\
\text { /Problem } \\
\text { gambling }\end{array}$} & $\begin{array}{l}\text { Kawa et al., } \\
2005\end{array}$ & $\begin{array}{l}\text { Cross- } \\
\text { sectional }\end{array}$ & $\begin{array}{l}\text { To examine } \\
\text { whether men } \\
\text { and women } \\
\text { with BD differ } \\
\text { in age of onset, } \\
\text { course of } \\
\text { illness, number } \\
\text { of suicide } \\
\text { attempts, } \\
\text { comorbidity } \\
\text { rates and } \\
\text { symptom } \\
\text { presentation }\end{array}$ & & DIGS & N/A & $\begin{array}{l}\text { Men: } n=90 \\
\text { Women: } \\
n=121\end{array}$ & $\begin{array}{l}\text { Onset of BDI: men }(26 \%) \text { vs. } \\
\text { women }(15 \%) ; \mathrm{P}=0.01 . \mathrm{PG} \text { : } \\
\text { men }(5 \%) \text { vs. women }(0 \%) ; \\
\mathrm{P}=0.01 \text {. } \\
\text { Alcohol abuse/dependence: } \\
\text { men }(32 \%) \text { vs. women }(20 \%) ; \\
\mathrm{P}<0.001 \text {. } \\
\text { Cannabis abuse/dependence: } \\
\text { men (19\%) vs. women }(12 \%) ; \\
\mathrm{P}=0.03 . \text { Eating disorders: } \\
\text { men }(1 \%) \text { vs. women }(13 \%) ; \\
\mathrm{P}<0.001\end{array}$ & \\
\hline & $\begin{array}{l}\text { Kennedy } \\
\text { et al., } 2010\end{array}$ & $\begin{array}{l}\text { Cross- } \\
\text { sectional }\end{array}$ & $\begin{array}{l}\text { To examine the } \\
\text { prevalence of } \\
\text { problem } \\
\text { gambling in } \\
\text { MDD or BD }\end{array}$ & $\begin{array}{l}\text { To examine sex } \\
\text { differences, } \\
\text { temporal } \\
\text { relationship } \\
\text { between onset of } \\
\text { mood disorder } \\
\text { and problem } \\
\text { gambling, } \\
\text { comorbidities, } \\
\text { quality of life }\end{array}$ & CPGI; TAG & N/A & $\begin{array}{l}\text { MDD: } \\
\mathrm{n}=275 \text { BD: } \\
\mathrm{n}=304 \\
\text { (BDI: } \\
\mathrm{n}=227 \\
74.6 \% \text {; BDII: } \\
\mathrm{n}=77 \\
25.3 \%)\end{array}$ & $\begin{array}{l}\text { Prevalence: } 12.5 \% \text { MDD } \\
(33 / 275) \text { vs. } 12.4 \% B D \\
(36 / 304) ; P>0.05\end{array}$ & $\begin{array}{l}\text { Mood disorder preceded onset } \\
\text { of PG. Comorbidities: mood } \\
\text { disorder with problem } \\
\text { gambling }(\mathrm{OR}=1.96 ; 95 \% \\
\mathrm{Cl}=1.02-3.75 ; \mathrm{P}=0.04) \text {. } \\
\text { Quality of life: } \mathrm{MDD} \text { [problem } \\
\text { gambling }(22.94 \pm 8.85) \text { vs. } \\
\text { non-problem gambling } \\
\text { (31.47 } \pm 11.65) ; \mathrm{P}<0.001] \text {; BD } \\
\text { [problem gambling } \\
(29.69 \pm 13.32) \text { vs. } \\
\text { non-problem gambling } \\
(35.29 \pm 13.47) ; \mathrm{P}=0.02]\end{array}$ \\
\hline & $\begin{array}{l}\text { Quilty } \\
\text { et al., } 2011\end{array}$ & $\begin{array}{l}\text { Cross- } \\
\text { sectional; } \\
\text { longitudinal }\end{array}$ & $\begin{array}{l}\text { To examine the } \\
\text { prevalence of } \\
\text { PG in a sample } \\
\text { of mood } \\
\text { disorder } \\
\text { patients }\end{array}$ & $\begin{array}{l}\text { To examine } \\
\text { association of PG } \\
\text { and mood } \\
\text { disorder }\end{array}$ & $\begin{array}{l}\text { SOGS; } \\
\text { CPGI; LIFE }\end{array}$ & $\mathrm{N} / \mathrm{A}$ & $\begin{array}{l}\text { Depressive } \\
\text { disorder: } \\
n=138 \text { BD: } \\
n=137 \\
\text { (BDI: } \\
n=100 \\
80.29 \% ; \\
\text { BDII: } n=21, \\
\text { 15.33\%; BD } \\
\text { NOS: } n=6, \\
4.38 \%)\end{array}$ & $\begin{array}{l}\text { Prevalence: } 4 \% \mathrm{BD} ; 7 \% \\
\text { depressive disorder }\end{array}$ & $\begin{array}{l}\text { Concurrent association: } P G \text { and } \\
\text { mood disorder } r=0.33 ; \\
P<0.01 \text {. Longitudinal } P G \text { and } \\
\text { mood disorder analyses } \\
\text { revealed no association }\end{array}$ \\
\hline
\end{tabular}


Table 2 (continued)

\begin{tabular}{|c|c|c|c|c|c|c|c|c|}
\hline Main BA & $\begin{array}{l}\text { First Author, } \\
\text { year }\end{array}$ & Study design & $\begin{array}{l}\text { Primary aim(s) } \\
\text { of the study }\end{array}$ & $\begin{array}{l}\text { Secondary aim(s) } \\
\text { of the study }\end{array}$ & $\begin{array}{l}\text { BA assess- } \\
\text { ment }\end{array}$ & $\begin{array}{l}\text { Criteria for } \\
\text { euthymia }\end{array}$ & $\begin{array}{l}\text { General } \\
\text { sample size }\end{array}$ & Secondary result(s) \\
\hline & $\begin{array}{l}\text { Jones et al., } \\
2015\end{array}$ & $\begin{array}{l}\text { Cross- } \\
\text { sectional }\end{array}$ & $\begin{array}{l}\text { To examine the } \\
\text { prevalence and } \\
\text { distribution of } \\
\text { PG in a sample } \\
\text { of BD patients }\end{array}$ & & PGSI & $\mathrm{N} / \mathrm{A}$ & BD: $n=635$ & $\begin{array}{l}\text { Distibution of PG: Moderate } \\
\text { or severe problem gambling: } \\
\mathrm{n}=67,10.55 \% ; \text { no or low } \\
\text { risk: } \mathrm{n}=658,89.45 \% \text {. Risk } \\
\text { factor for Moderate or severe } \\
\text { problem gambling were a } \\
\text { history of suicidal ideation or } \\
\text { attempt }(\mathrm{OR}=3.44 ; \\
95 \% \mathrm{Cl}=1.21-9.73 ; \mathrm{P}=0.02) \text {, } \\
\text { history of rapid cycling } \\
(\mathrm{OR}=2.63 ; \\
95 \% \mathrm{Cl}=1.29-5.34 ; \\
\mathrm{P}=0.008) \text {, and younger age } \\
\text { at illness onset }(\mathrm{OR}=0.94 ; \\
95 \% \mathrm{Cl}=0.90-0.98 ; \mathrm{P}=0.002)\end{array}$ \\
\hline & $\begin{array}{l}\text { Quilty } \\
\text { et al., } 2017\end{array}$ & Longitudinal & $\begin{array}{l}\text { To examine the } \\
\text { association } \\
\text { between } \\
\text { affect, desire } \\
\text { to gamble and } \\
\text { gambling } \\
\text { behavior in } \\
\text { individuals with } \\
\text { a mood } \\
\text { disorder }\end{array}$ & & SOGS; RFG & N/A & $\begin{array}{l}\text { Depressive } \\
\text { disorder: } \\
n=15 \text { BD: } \\
n=15 \text { (BDI: } \\
n=14 \text {, } \\
93.3 \% \text {;DII: } \\
n=1,6.6 \% \text { ) }\end{array}$ & $\begin{array}{l}\text { Affect predicted the desire } \\
\text { to gamble, not the gambling } \\
\text { behavior. Desire to gamble } \\
\text { predicted gambling behavior. } \\
\text { Gambling motivations: at } \\
\text { base line: no differences; at } \\
\text { 30-day period BD copes with } \\
\text { negative affect and } \\
\text { depressive disorder social } \\
\text { reasons or enhancement of } \\
\text { positive affect }\end{array}$ \\
\hline
\end{tabular}


Table 2 (continued)

Main BA First Author, Study design Primary aim(s) Secondary aim(s) BA assess- Criteria for General Primary result(s)

Mear
of the study of the study ment euthymia sample size

Compulsive Kesebir To examine the To examine the

CBS

N/A

BD: $n=100 ; \quad C B: B D(8 \%) ; H C(0 \%)$
$H C: n=100$

buying (CB) et al., 2012 sectional frequency of differences

Case-control $C B$ in $B D$ and to between

compare it $\mathrm{CB}+$ and $\mathrm{CB}$ -
with $\mathrm{HC}$

with $\mathrm{HC}$

To examine the To examine prevalence of ICD + /ICD- on variables and levels of impulsivity/ sensation seeking lifetime ICD in sociodemographic, clinical

\section{MIDI} BDI
CB, klepto- 2011

mania, PG

and

compulsiv

behavior)

$\begin{array}{ll}\text { BDI } & \text { graphic, clinical } \\ & \text { variables and } \\ & \text { levels of } \\ & \text { impulsivity/ } \\ & \text { sensation } \\ \text { seeking }\end{array}$

Abbreviations: $\mathrm{BD}=$ Bipolar Disorder; $\mathrm{BDI}=$ Bipolar Disorder type I; $\mathrm{BA}+=\mathrm{BD}$ with $\mathrm{BA} ; \mathrm{BA}-=\mathrm{BD}$ without $\mathrm{BA} ; \mathrm{CB}+=\mathrm{BD}$ with $\mathrm{CB}$; $\mathrm{CB}-=\mathrm{BD}$ without $\mathrm{ICD}$; $\mathrm{CBS}=\mathrm{Compulsive} \mathrm{Buying} \mathrm{Scale}$

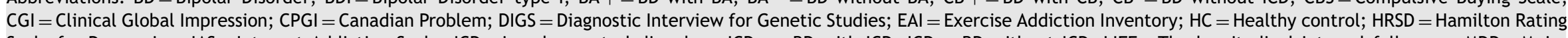

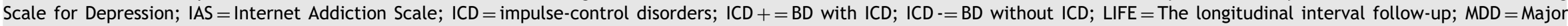

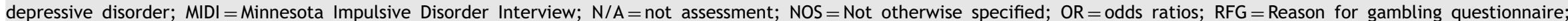
SAST = Sexual Addiction Screening Test; SOGS = South Oaks Gambling Screen; TAG = Temporal Assessment of Gambling; WART = Work Addiction Risk Test; YMRS = Young Mania Rating Scale.

$\mathrm{CB}-(2.4 \%) ; \mathrm{p}=0.025$. Working $\mathrm{CB} \pm(75 \%)$ vs. $\mathrm{CB}-(52 \%)$ $\mathrm{P}=0.035$. Premenstrual syndrome: $\mathrm{CB} \pm(75 \%)$ vs. $C B-(32.6 \%) ; P=0.002$. Postpartum onset: $\mathrm{CB} \pm(62.5 \%$ vs. $C B-(32.6 \%) ; P=0.009$. First episode mania: $C B \pm(75 \%)$ vs. CB-(41.3\%); $P=0.007$. Severity of episode: $C B \pm(1.5 \pm 0.1)$ vs. CB- $(2.2 \pm 0.2) ; \mathrm{P}=0.01$

Number of episodes:

$\mathrm{CB} \pm(2.3 \pm 0.2)$ vs

$C B-(0.9 \pm 0.1) ; P=0.002$.

Inter-episode full remission: $P=0.001$. Axis II co-morbidity: $\mathrm{CB} \pm(162.5 \%)$ vs. $\mathrm{CB}-(43.4 \%)$ temperament scores: $\mathrm{CB} \pm$ (17.3) vs. $\mathrm{CB}-(15.4)$ $\mathrm{P}=0.029$. Irritable temperament scores $\mathrm{CB} \pm$ (23.2) vs. $\mathrm{CB}-(21.8)$;

$\mathrm{CD}+$ higher comorbidity of HDRS $<8$

(pathologic skin picking $n=13 ; C B ~ n=9 ;$ Interm
explosive disorder $n=8$; trichotillomania $n=8 ; P G$ $\mathrm{n}=4$; kleptomania $\mathrm{n}=1$; compulsive exercise $\mathrm{n}=1$; compulsive sexual behavior alcohol/SUD $(P=0.03)$, highe ( attempts $(P=0.024)$, more depressive episodes $(P<0.01)$, and higher impulsivity scores $(P=0.035)$ than ICD $\mathrm{n}=0$ ) 


\section{Behavioral addition (BA)}

Across the 2 studies there were a total of 208 people with BD.

A cross-sectional study examined the prevalence of BA in a sample of 158 euthymic bipolar patients compared with 200 healthy controls (HC) (Di et al., 2010). Clinical variables, level of impulsivity and temperamental dimensions were also compared between BD with and without BA. Results showed that bipolar patients presented higher BA comorbidity rates compared to $\mathrm{HC}$ ( $33 \%$ vs. $13 \%)$. Among patients with $\mathrm{BD}$, compulsive buying $(17 \%)$ was more frequent followed by work addiction (13\%), PG (7\%), compulsive sexual behavior (3\%) and exercise addiction (4\%). Furthermore, $\mathrm{BD}$ patients with BA were more likely to present axis II comorbidity than BD patients without BA. When temperament was analysed, the results revealed significantly lower self-directness and cooperativeness scores and significantly higher impulsivity levels in patients with BA with respect to those without BA.

Another study compared 50 BD type I with $50 \mathrm{HC}$ concerning BA (Sapir et al., 2013). BA were divided into two categories: harmful addictions (alcohol, drugs, cigarettes and gambling), and benign addictions (chocolate, caffeine, exercise, shopping, internet, love relationships, music and work). Post-hoc comparisons revealed significant differences between $B D$ patients and $\mathrm{HC}$ in several individual BA. BD showed higher scores on two benign BA (music and shopping) and smoking. Personality traits were also studied; the results showed that, in both groups, novelty-seeking was positively associated with harmful addictions while cooperativeness was negatively associated with harmful addictions.

\section{Pathological gambling / problem gambling}

Across the 5 studies there were a total of 1302 people with BD.

An exploratory cross-sectional study examined whether men and women with BD differed in comorbidity rates (Kawa et al., 2005). Among 90 men with BD, 5\% met criteria diagnosis for PG, none of the 121 women met criteria diagnosis for PG.

Another study aimed to investigate the frequency of problem gambling, clinical features and comorbidities in a sample of 275 patients with major depressive disorder and 304 patients with BD (Kennedy et al., 2010). The results showed that prevalence of problem gambling did not significantly differ between major depressive disorder (12.5\%) and BD (12.3\%) groups. Regarding mood symptom severity, patients with major depressive disorder and BD meeting criteria for problem gambling scored significantly higher on depressive symptoms compared with non-problem gambling. $\mathrm{BD}$ patients with comorbid specific phobia, alcohol dependence, and SUD had significantly an increased risk of experiencing problem gambling.

A cross-sectional study examined the prevalence of problem gambling in 635 patients with $\mathrm{BD}$, with a particular focus on differences between BDI and BDII (Jones et al., 2015). Additionally, the associations between problem gambling and lifetime clinical variables in BD were analyzed. The results revealed that moderate to severe problem gambling was four times higher in BD than in the general population ( $11 \%$ and $3 \%$ respectively). Among patients with BDII,
$15 \%(n=27)$ were rated as being at moderate or severe risk compared with $10 \%(n=40)$ of those with BDI. Results also showed that clinical variables associated with the presence of moderate and severe risk of problem gambling were having history of suicidal ideation or attempt, history of rapid cycling, and younger age at illness onset.

A cross-sectional and longitudinal study focused on evaluating the prevalence and the association of PG in a sample of outpatients with diagnosis of depressive spectrum disorder, $(n=138)$ and BD $(n=137)$ (Quilty et al., 2011). The prevalence rate of PG evaluated with conservative criteria was $7 \%$ in patients with depressive spectrum disorder and $4 \%$ in $B D$, without significant differences between both groups. Despite the concurrent association between PG and mood disorder symptoms $(r=0.33 ; p<0.01)$, over past 5 years no longitudinal association was found between both pathologies.

The prospective associations between affect, desire to gamble, and gambling behavior in individuals diagnosed with a mood disorder were evaluated (Quilty et al., 2017). Thirty patients with a lifetime diagnosis of unipolar depressive disorder $(n=15)$ or BD $(n=15)$ who met criteria for current and lifetime PG were enrolled in this study. Results revealed similar gambling motivations across groups at baseline. However, during the 30 -day period BD participants were significantly more likely to use gambling to cope with negative affect (46\% vs. $22 \%$ ) while participants with depressive disorder were significantly more likely to endorse gambling for social reasons ( $8 \%$ vs. $3 \%$ ) and for enhancing the emergence of positive affect $(69 \%$ vs. $51 \%)$. Regression analysis revealed mood-related variables such as high levels of sadness and arousal predicted an increased desire to gamble and therefore gambling behaviors.

\section{Compulsive buying}

Across the 2 studies there were a total of 109 people with $\mathrm{BD}$

Outpatients with BD were assessed for the frequency of compulsive buying in a cross-sectional study (Kesebir et al., 2012) that included 100 BD patients and $100 \mathrm{HC}$. Compulsive buying was more prevalent in $\mathrm{BD}$ patients $(8 \%)$ than in $\mathrm{HC}(0 \%)$. Premenstrual syndrome was significantly more frequent in compulsive buying BD patients, as well as postpartum onset than BD patients without compulsive buying. The former group presented statistically more frequent manic onset of illness, and lower episode severity prior to prophylactic treatment. Additionally, axis II comorbidity rates were increased among compulsive buying BD patients. When temperament scores were analyzed, cyclothymic and irritable temperament scores were significantly more prevalent in compulsive buying BD than in non-comorbid BD patients.

In a cross-sectional study, the prevalence of lifetime compulsive buying and other ICD such as PG, kleptomania and compulsive sexual behavior was examined within a sample of 124 euthymic BDI (Karakus and Tamam, 2011). Results revealed that among bipolar patients with an ICD $(\mathrm{n}=34,27.4 \%)$ the prevalence of compulsive buying was higher (7.3\%) compared with PG (3.2\%), kleptomania $(0.8 \%)$ and compulsive sexual behavior $(0 \%)$ in this group of psychiatric patients. Regarding clinical variables, results showed that BD patients with ICD compared with BD patients without them presented higher rates of comorbidity with 
alcohol or any other SUD, higher number of previous suicidal attempts, more depressive episodes, and higher level of impulsivity.

\section{Specific treatments for comorbid BD and BA}

One study fulfilled the inclusion criteria (McElroy et al., 2008). This randomized placebo-controlled trial study evaluated the efficacy and safety of olanzapine in the treatment of PG. The sample consisted in 42 outpatients with PG out of which 21 received olanzapine and 21 received placebo during 12 weeks. Among the sample, 19\% had a BD diagnosis ( $n=2$ olanzapine; $n=6$ placebo). The results showed that olanzapine and placebo were associated with a similar rate of reduction in the total scores on the Yale-Brown Obsessive Compulsive Scale, as well as in gambling episodes/week, hours gambled/week, and in the Clinical Global Impressions-Severity of Illness scale scores.

\section{Discussion}

To our knowledge, this is the first systematic review specifically aimed to examine the relationship between $B A$ and $B D$. BD-BA co-occurrence seems to be high, PG being the most common among this group of patients, followed by kleptomania, compulsive buying, compulsive sexual behavior and, finally, IA. We did not find results concerning BD and others BA. Overall, our results suggest that, compared to patients without BA, bipolar patients with concurrent BA present a worse prognosis and more severe course of illness, higher rates of axis I comorbidity, suicidal ideation and behavior, early age at onset and higher levels of impulsivity. No treatments are currently approved for BA-BD comorbidity; we identified only one randomized controlled trial that has sought to address this issue in people with BD. Additionally, methodological heterogeneity in terms of design among studies was found.

Clinical and epidemiological research revealed high rates of comorbidity between $\mathrm{BA}$ and psychiatric disorders (Chamberlain et al., 2016; Grant et al., 2010). The most prevalent seems to be mood disorders, anxiety disorders, SUD and PD. Yet, results globally point at a higher occurrence of $\mathrm{BA}-\mathrm{BD}$ comorbidity compared with the general population. The prevalence of $\mathrm{BD}$ patients in $\mathrm{BA}$ samples ranges from $1 \%$ to $68 \%$ (Kim et al., 2016; Lejoyeux et al., 2002) and the prevalence of $\mathrm{BA}$ in $\mathrm{BD}$ samples tend to vary from 3\% to 33\% (Karakus and Tamam, 2011; Di et al., 2010). Individuals with BA present a higher risk to be diagnosed as $\mathrm{BD}$, esteemed with OR ranging from 1.5 to 4 (Zimmerman et al., 2006; Abdollahnejad et al., 2014). Together with the fact that there are many studies with small sample size, the variability in the assessment of BA, may partially account for the heterogeneity in our results. Another possible explanation could be that the number of studies found for BA are very widely different. For instance, PG prevalence in $\mathrm{BD}$ ranges from $2 \%$ to $68 \%$, approximately (Edens and Rosenheck, 2012; Kausch, 2004), kleptomania from 4\% to 75\% (Lejoyeux et al., 2002; Dannon et al., 2004). However, it is worth mentioning that the highest percentage of bipolar patients with kleptomania must be interpreted with caution because could be causing by the small sample size of patients with kleptomania $(n=4)$ that appeared in the study by Lejotyeux and colleagues. Another BA, compulsive buying and compulsive sexual behavior seem also prevalent. Regarding the former, overspending can also be problems for BD compared to other disorders (Blanco et al., 2008). Different studies found that compulsive buying scores in bipolar patients were higher than those in $\mathrm{HC}$ ( $\mathrm{Di}$ et al., 2010; Kesebir et al., 2012). In addition, it has been described that up to $7-8 \%$ of individuals fulfilled compulsive buying criteria in samples of individuals with BD (Kesebir et al., 2012; Karakus and Tamam, 2011), a percentage that is higher than that reported in the general population $(3.1 \%)$ (Mueller et al., 2009). Concerning compulsive sexual behavior, its prevalence among BD patients was low (overall 4-8\%) compared with other diagnostic categories studied, as any other mood, anxiety disorders and SUD (Raymond et al., 2003; Scanavino et al., 2013). Regarding IA, it is still not clear whether it constitutes a BA per se or if it simply channels $B A$, routing patients to compulsive online pornography viewing, compulsive online shopping, or internet gaming disorder (Chamberlain et al., 2016). The prevalence's rate of comorbidity between BD from problematic internet to IA among BD was 1-7\% (Kim et al., 2016; Bernardi and Pallanti, 2009). As aforementioned with kleptomania, results about some BA such as, compulsive sexual behavior and problem internet use must be interpreted with caution since the numbers of studies is small as well as the sample of patients with BD; hence it is difficult to draw firm conclusions about their relationship. It is worth mentioning that diagnostic reliability of most BA is poor, with the exception of PG.

Beyond the overall worsening effect of comorbid BA in $B D$, another critical aspect that needs to be further investigated is the directional relation between the two disorders, BA has been viewed as an attempt to self-medicate or escape negative mood states (Goldstein and Bukstein, 2010). The increased prevalence of BD in BA populations (Di et al., 2010; Sapir et al., 2013) points to the possibility that either $\mathrm{BA}$ may trigger or predispose to $\mathrm{BD}$ or $\mathrm{BD}$ may predispose to BA through increased sensitivity to rewarding stimuli or through self-treatment. Since, a trend towards mood elevation and symptoms of hypomania, as well as an orientation towards reward-based behaviors, might drive to develop a BA by enhancing its enjoyment and excitement. On the contrary, depressive symptoms could provide an impetus to console or comfort oneself through BA. In this sense, the relatively strong associations between $\mathrm{BD}$ and PG may be explained by the fact that the characteristic mood disturbances of BD could be playing a powerful role in the development and maintenance of gambling problems in this population (Jones et al., 2015). Actually, various forms of mood disturbance are associated with divergent motivations that might represent distinct pathways into gambling behavior (Lloyd et al., 2010), participants with BD were likely to endorse gambling to cope with negative affect (Quilty et al., 2017). Urge of BA are often associated with arousal and restlessness that resemble the elevated mood or with tension and anxiety, similar to that which can occur in depressive or mixed states (Cunningham-Williams et al., 1998). In this sense, BA-BD comorbidity may pose as a differential diagnostic challenge, and has to be ruled out in the 
assessment of possible acute depressive-mixed recurrences in $\mathrm{BD}$.

An early BD onset (Jones et al., 2015; Kausch, 2004; Kessler et al., 2008), and being male (Kawa et al., 2005; Kennedy et al., 2010; Manning et al., 2017) could be associated with risk factors for BD and BA. So, the implementation of early intervention strategies may help to change the outcome of the illness and avert potentially irreversible harm to patients with $\mathrm{BD}$, as early phases may be more responsive to treatment (Vieta et al., 2018b).

When personality traits were analyzed among BD with comorbid BA, self-directness and cooperativeness scores were significantly lower and impulsivity levels significantly higher compared with BD patients without comorbid BA (Kesebir et al., 2012; Di et al., 2010; Sapir et al., 2013; Karakus and Tamam, 2011). Taking these results together, impulsivity, poor modulation of motivation, poor modulation of response to rewarding stimuli, combined with susceptibility to behavioral sensitization are other mechanisms that would reinforce a neurocognitive link between $B D$ and $B A$ (Swann, 2010). Additionally, impulsivity may be associated with greater likelihood of severe suicidal behavior in BD (Swann et al., 2004; Jimenez et al., 2016). Interactions between impulsivity and other risk factors for suicide, including $B A$, require further investigation.

Undoubtedly, even lower evidence on potential treatments for BD-BA comorbidity exists. To ensure the internal valid of the findings, many randomized controlled trials exclude patients with multiple comorbird condition. The only trial on treatment that fulfilled inclusion criteria was negative, olanzapine did not showed a significant improvement over the placebo group respect to reduction in gambling behavior and urges (McElroy et al., 2008). Although the few available literature suggest that mood stabilizers could be an effective treatment approach for BD-BA(Di et al., 2014), most data is based on case reports with lithium(Moskowitz, 1980; Rocha and Rocha, 1992), tomiramate (Nicolato et al., 2007) or a single case with carbamazepine(Haller and Hinterhuber, 1994). In a small randomized control trial, lithium was found to be effective in reducing gambling behavior and effective instability in BD-PG (Hollander et al., 2005b); however, this study was excluded from our results as BD diagnostic was assessed by a screening tool. No pharmacologic or psychological treatments are currently approved for BA (Hollander et al., 2005a; Nicolato et al., 2007; McElroy et al., 2008). For this reason, the management of comorbid BA-BD patients was addressed at symptom dimensions. The clinical management of BD-BA comorbidity should prioritize affective instability and ensure mood regulation first then treats the BA symptoms if still necessary ( $\mathrm{Di}$ et al., 2014). There are identifiable risk factors that influence the course of BD, some of them potentially modifiable (Vieta et al., 2018c). Adjunctive psychological interventions that have shown to prevent relapses (e.g., psychoeducation, family intervention, cognitive-behavioral therapy and interpersonal and social rhythm therapy) and to improve mood-regulation in BD (Reinares et al., 2014) should be considered. Presumably, this kind of interventions might be beneficial at least to mitigate the potential impact of $B D$ on BA. Although no specific evidence on BA-BD comorbidity exists, successful therapeutic interventions for BA include approaches based on the 12-step model, motivational interviewing, and cognitive behavioral therapies, so that they could be taken into consideration in the treatment of comorbid BA-BD too (Kennedy et al., 2010).

Our results need to be interpreted in the light of several limitations. First, many of the methodological limitations of the studies may impact on our results, preventing us from drawing firm conclusions. Thus, the fact that many studies included small sample sizes and restricted assessments limit the generalizability of the findings. Taken together, this point out to an overall poor quality in the evidence so far, produced on this specific population, and calls for more methodological sound studies, with more homogenous population. Moreover, due to the cross-sectional design of most studies, the directionality of the association between BA and BD could not be established. Although the presence of manic episodes has been defined as an exclusion criterion of PG (American Psychiatric Association, 2013), we found a large variability in the definition of euthymia, when reported, and most of the studies did not provide this information. Regarding BA, we found differences in the number of studies found for each BA, nomenclature, definitions, and operational criteria about what constitutes BA, as well as screening instruments used.

Future research in the young field of BA and BA-BD comorbidity should focus on narrowing diagnostic criteria for BA, improving their diagnostic reliability. Consequently, assessment should be created and validated in order to allow quantitative, dimensional measurements and possible symptomatic domains. Once stable BA populations could be detected, causal relationships between BA and BD could be investigated, outlining possible risk factors and the neurobiological underpinnings for BA-BD comorbidities.

\section{Conclusions}

So far, literature on BA and BD comorbidity suggest the existence of an increased co-occurrence of these conditions. Our findings highlight the need to undertake systematic and routine screening and comprehensive assessment of possible co-occurring $\mathrm{BA}$ in $\mathrm{BD}$, given the potential negative impact that BA may bring directly on bipolar illness and, more in general, to the impairment in the social, relational, economic and quality of life of patients suffering from these conditions. Shared neurobiological underpinnings can be hypothesized in high levels of impulsivity and emotional instability, but have to be ascertained and fully understood. A better assessment and understanding of the relationship between $B A$ and $B D$ in future research should contribute to the improved identification of $B D$ individuals at risk of $B A$. Comorbid BA-BD patients should also be assessed in their potentially differential treatment response. Forthcoming research will possibly help identifying novel targets for treatment and, ultimately, improve the outcome of both conditions.

\section{Conflict of interests}

Dr. Martinez-Aran has served as speaker or advisor for the following companies: Bristol-Myers Squibb, Otsuka, Lundbeck and Pfizer. 
Dr. Vieta has received grants, CME-related honoraria, or consulting fees from AB-Biotics, Actavis, Alexza, Almirall, Allergan, AstraZeneca, Bristol-Myers Squibb, Cephalon, Dainippon Sumitomo Pharma, Eli Lilly, Ferrer, Forest Research Institute, Gedeon Richter, GlaxoSmith-Kline, Janssen, Janssen-Cilag, Jazz, Johnson and Johnson, Lundbeck, Merck, Novartis, Organon, Otsuka, Pfizer, PierreFabre, Qualigen, Roche, Sanofi-Aventis, Schering-Plough, Servier, Shire, Solvay, Sunovion, Takeda, Teléfónica, Teva, the Spanish Ministry of Science and Innovation (CIBERSAM), the Brain and Behaviour Foundation, the Seventh European Framework Programme (ENBREC), the Stanley Medical Research Institute, United Biosource Corporation, and Wyeth. The other authors report no financial relationships with commercial interests.

The other authors report no financial relationships with commercial interests.

All other authors report no biomedical financial interests or potential conflicts of interest.

\section{Contributors}

All authors contributed equally. All authors had critically reviewed and contributed to manuscript. All authors approved the final version of the paper.

\section{Role of the funding source}

Not applicable. This research received no specific grant from any funding agency, commercial or not-for-profit sectors.

\section{Acknowledgments}

E.V. is grateful for the support received from the Instituto de Salud Carlos III, Ministry of Science, Innovation and Universities (PI15/00283), integrated into the Plan Nacional de I+D+I and co-funded by ISCIII-Subdirección General de Evaluación and Fondo Europeo de Desarrollo Regional (FEDER); Centro para la Investigación Biomédica en Red de Salud Mental (CIBERSAM), Secretaria d'Universitats i Recerca del Departament d'Economia i Coneixement (2017 SGR 1365), the Seventh European Framework Programme (ENBREC); the Stanley Medical Research Institute and the project SLT006/17/00357, from PERIS 2016-2020 (Departament de Salut). CERCA Programme/Generalitat de Catalunya

A.F.C. is supported by a research fellowship award from the Conselho Nacional de Desenvolvimento Científico e Tecnológico (CNPq; Brazil).

\section{Reference}

Abdollahnejad, M.R., Delfabbro, P., Denson, L., 2014. The clustering of psychiatric disorders in high-risk gambling populations. J. Gambl. Stud. 30, 933-947.

American Psychiatric Association, 2013. Diagnostic and Statistical Manual of Mental disorders, 5th Edition (DSM-5). Author, Washington, DC ed.
Ascher, M., Levounis, P., 2015. The Behavioral Addictions. American Psychiatric Association ed, Washington, London.

Bayle, F.J., Caci, H., Millet, B., Richa, S., Olie, J.P., 2003. Psychopathology and comorbidity of psychiatric disorders in patients with kleptomania. Am. J. Psychiatry 160, 1509-1513.

Bernardi, S., Pallanti, S., 2009. Internet addiction: a descriptive clinical study focusing on comorbidities and dissociative symptoms. Compr. Psychiatry 50, 510-516.

Black, D.W., 2007. Compulsive buying disorder: a review of the evidence. CNS. Spectr. 12, 124-132.

Black, D.W., Moyer, T., 1998. Clinical features and psychiatric comorbidity of subjects with pathological gambling behavior. Psychiatr. Serv. 49, 1434-1439.

Blanco, C., Grant, J., Petry, N.M., Simpson, H.B., Alegria, A., Liu, S.M., et al., 2008. Prevalence and correlates of shoplifting in the United States: results from the National Epidemiologic Survey on Alcohol and Related Conditions (NESARC). Am. J. Psychiatry 165, 905-913.

Cardoso, T.A., Mondin, T.C., Souza, L.D., da Silva, R.A., Magalhaes, P.V., Kapczinski, F., et al., 2015. Functioning in bipolar disorder with substance abuse/dependence in a community sample of young adults. J. Affect. Disord. 187, 179-182.

Chamberlain, S.R., Lochner, C., Stein, D.J., Goudriaan, A.E., van Holst, R.J., Zohar, J., et al., 2016. Behavioural addiction-A rising tide. Eur. Neuropsychopharmacol 26, 841-855.

Cunningham-Williams, R.M., Cottler, L.B., Compton III, W.M., Spitznagel, E.L., 1998. Taking chances: problem gamblers and mental health disorders-results from the St. Louis Epidemiologic Catchment Area Study. Am. J. Public Health 88, 1093-1096.

Dannon, P.N., Lowengrub, K., Aizer, A., Kotler, M., 2006. Pathological gambling: comorbid psychiatric diagnoses in patients and their families. Isr. J. Psychiatry Relat. Sci. 43, 88-92.

Dannon, P.N., Lowengrub, K.M., lancu, I., Kotler, M., 2004. Kleptomania: comorbid psychiatric diagnosis in patients and their families. Psychopathology 37, 76-80.

DeCaria, C.M., Hollander, E., Grossman, R., Wong, C.M., Mosovich, S.A., Cherkasky, S., 1996. Diagnosis, neurobiology, and treatment of pathological gambling. J. Clin. Psychiatry 57 (Suppl 8), 80-83.

Demetrovics, Z., Griffiths, M.D., 2012. Behavioral addictions: Past, present and future. J. Behav. Addict. 1, 1-2.

Di, N.M., De, R.L., Pettorruso, M., Caselli, G., De, C.F., Swierkosz-Lenart, K., et al., 2014. Bipolar disorder and gambling disorder comorbidity: current evidence and implications for pharmacological treatment. J. Affect. Disord. 167, 285-298.

Di, N.M., Tedeschi, D., Mazza, M., Martinotti, G., Harnic, D., Catalano, V., et al., 2010. Behavioural addictions in bipolar disorder patients: role of impulsivity and personality dimensions. J. Affect. Disord. 125, 82-88.

Edens, E.L., Rosenheck, R.A., 2012. Rates and correlates of pathological gambling among VA mental health service users. J. Gambl. Stud 28, 1-11.

Goldstein, B.I., Bukstein, O.G., 2010. Comorbid substance use disorders among youth with bipolar disorder: opportunities for early identification and prevention. J. Clin. Psychiatry 71, 348-358.

Goodman, A., 1992. Sexual addiction: designation and treatment. J. Sex Marital Ther. 18, 303-314.

Grande, I., Berk, M., Birmaher, B., Vieta, E., 2016. Bipolar disorder. Lancet 387, 1561-1572.

Grant, J.E., Potenza, M.N., Weinstein, A., Gorelick, D.A., 2010. Introduction to behavioral addictions. Am. J. Drug Alcohol Abuse 36, 233-241.

Haller, R., Hinterhuber, H., 1994. Treatment of pathological gambling with carbamazepine. Pharmacopsychiatry 27 (129).

Hodgins, D.C., Peden, N., Cassidy, E., 2005. The association between comorbidity and outcome in pathological gambling: a 
prospective follow-up of recent quitters. J. Gambl. Stud. 21, 255-271.

Hollander, E., Pallanti, S., Allen, A., Sood, E., Baldini, R.N., 2005a. Does sustained-release lithium reduce impulsive gambling and affective instability versus placebo in pathological gamblers with bipolar spectrum disorders? Am. J. Psychiatry 162, 137-145.

Hollander, E., Pallanti, S., Allen, A., Sood, E., Baldini, R.N., 2005b. Does sustained-release lithium reduce impulsive gambling and affective instability versus placebo in pathological gamblers with bipolar spectrum disorders? Am. J. Psychiatry 162, 137-145.

Jimenez, E., Arias, B., Mitjans, M., Goikolea, J.M., Ruiz, V., Brat, M., et al., 2016. Clinical features, impulsivity, temperament and functioning and their role in suicidality in patients with bipolar disorder. Acta Psychiatr. Scand 133, 266-276.

Jones, L., Metcalf, A., Gordon-Smith, K., Forty, L., Perry, A., Lloyd, J., et al., 2015. Gambling problems in bipolar disorder in the UK: prevalence and distribution. Br. J. Psychiatry 207, 328-333.

Kafka, M.P., Prentky, R., 1992. Fluoxetine treatment of nonparaphilic sexual addictions and paraphilias in men. J. Clin. Psychiatry 53, 351-358.

Karakus, G., Tamam, L., 2011. Impulse control disorder comorbidity among patients with bipolar I disorder. Compr. Psychiatry 52, 378-385.

Kausch, O., 2004. Pathological gambling among elderly veterans. J. Geriatr. Psychiatry Neurol. 17, 13-19.

Kawa, I., Carter, J.D., Joyce, P.R., Doughty, C.J., Frampton, C.M., Wells, J.E., et al., 2005. Gender differences in bipolar disorder: age of onset, course, comorbidity, and symptom presentation. Bipolar. Disord. 7, 119-125.

Kennedy, S.H., Welsh, B.R., Fulton, K., Soczynska, J.K., Mclntyre, R.S., O'Donovan, C., et al., 2010. Frequency and correlates of gambling problems in outpatients with major depressive disorder and bipolar disorder. Can. J. Psychiatry 55, 568-576.

Kesebir, S., 2012. Comorbid impulse control disorder in bipolar disorder: the role of antidepressants. Turk. Psikiyatri. Derg. 23 (71).

Kesebir, S., Isitmez, S., Gundogar, D., 2012. Compulsive buying in bipolar disorder: is it a comorbidity or a complication? J. Affect. Disord. 136, 797-802.

Kessler, R.C., Hwang, I., LaBrie, R., Petukhova, M., Sampson, N.A., Winters, K.C., et al., 2008. DSM-IV pathological gambling in the National Comorbidity Survey Replication. Psychol. Med. 38, 1351-1360.

Kim, B.S., Chang, S.M., Park, J.E., Seong, S.J., Won, S.H., Cho, M.J., 2016. Prevalence, correlates, psychiatric comorbidities, and suicidality in a community population with problematic Internet use. Psychiatry Res. 244, 249-256.

Ko, C.H., Yen, J.Y., Yen, C.F., Chen, C.S., Chen, C.C., 2012. The association between Internet addiction and psychiatric disorder: a review of the literature. Eur. Psychiatry 27, 1-8.

Lejoyeux, M., Arbaretaz, M., McLoughlin, M., Ades, J., 2002. Impulse control disorders and depression. J. Nerv. Ment. Dis 190, 310-314.

Lejoyeux, M., Mc, L.M., Ades, J., 2000. Epidemiology of behavioral dependence: literature review and results of original studies. Eur. Psychiatry 15, 129-134.

Lloyd, J., Doll, H., Hawton, K., Dutton, W.H., Geddes, J.R., Goodwin, G.M., et al., 2010. How psychological symptoms relate to different motivations for gambling: an online study of internet gamblers. Biol. Psychiatry 68, 733-740.

Manning, V., Dowling, N.A., Lee, S., Rodda, S., Garfield, J.B.B., Volberg, R., et al., 2017. Problem gambling and substance use in patients attending community mental health services. J. Behav. Addict. 6, 678-688.

McElroy, S.L., Nelson, E.B., Welge, J.A., Kaehler, L., Keck Jr., P.E., 2008. Olanzapine in the treatment of pathological gambling: a negative randomized placebo-controlled trial. J. Clin. Psychiatry 69, 433-440.

McIntyre, R.S., McElroy, S.L., Konarski, J.Z., Soczynska, J.K., Wilkins, K., Kennedy, S.H., 2007. Problem gambling in bipolar disorder: results from the Canadian Community Health Survey. J. Affect. Disord. 102, 27-34.

Medeiros, G.C., Redden, S.A., Chamberlain, S.R., Grant, J.E., 2017. Gambling disorder: association between duration of illness, clinical, and neurocognitive variables. J. Behav. Addict. 6, 194-202.

Moher, D., Liberati, A., Tetzlaff, J., Altman, D.G., 2009. Preferred reporting items for systematic reviews and meta-analyses: the PRISMA statement. PLoS.Med. 6 e1000097.

Moskowitz, J.A., 1980. Lithium and lady luck; use of lithium carbonate in compulsive gambling. N.Y. State J. Med. 80, 785-788.

Mueller, A., Muhlhans, B., Silbermann, A., Muller, U., Mertens, C., Horbach, T., et al., 2009. Compulsive buying and psychiatric comorbidity. Psychother. Psychosom. Med. Psychol. 59, 291-299.

Murru, A., Pacchiarotti, I., Amann, B.L., Nivoli, A.M., Vieta, E., Colom, F., 2013. Treatment adherence in bipolar I and schizoaffective disorder, bipolar type. J. Affect. Disord. 151, 1003-1008.

Nicolato, R., Romano-Silva, M.A., Correa, H., Salgado, J.V., Teixeira, A.L., 2007. Lithium and topiramate association in the treatment of comorbid pathological gambling and bipolar disorder. Aust. N.Z.J. Psychiatry 41 (628).

Nower, L., Eyrich-Garg, K.M., Pollio, D.E., North, C.S., 2015. Problem gambling and homelessness: results from an epidemiologic study. J. Gambl. Stud. 31, 533-545.

Nunes-Neto, P.R., Kohler, C.A., Schuch, F.B., Solmi, M., Quevedo, J., Maes, M., et al., 2018. Food addiction: prevalence, psychopathological correlates and associations with quality of life in a large sample. J. Psychiatr. Res. 96, 145-152.

Ostergaard, M.L.D., Nordentoft, M., Hjorthoj, C., 2017. Associations between substance use disorders and suicide or suicide attempts in people with mental illness: a Danish nation-wide, prospective, register-based study of patients diagnosed with schizophrenia, bipolar disorder, unipolar depression or personality disorder. Addiction 112, 1250-1259.

Petry, N.M., Stinson, F.S., Grant, B.F., 2005. Comorbidity of DSM-IV pathological gambling and other psychiatric disorders: results from the National Epidemiologic Survey on Alcohol and Related Conditions. J. Clin. Psychiatry 66, 564-574.

Porter, G., Starcevic, V., Berle, D., Fenech, P., 2010. Recognizing problem video game use. Aust. N.Z.J. Psychiatry 44, 120-128.

Presta, S., Marazziti, D., Dell'Osso, L., Pfanner, C., Pallanti, S., Cassano, G.B., 2002. Kleptomania: clinical features and comorbidity in an Italian sample. Compr. Psychiatry 43, 7-12.

Quilty, L.C., Watson, C., Robinson, J.J., Toneatto, T., Bagby, R.M., 2011. The prevalence and course of pathological gambling in the mood disorders. J. Gambl. Stud 27, 191-201.

Quilty, L.C., Watson, C., Toneatto, T., Bagby, R.M., 2017. A prospective investigation of affect, the desire to gamble, gambling motivations and gambling behavior in the mood disorders. J. Gambl. Stud. 33, 115-129.

Raymond, N.C., Coleman, E., Miner, M.H., 2003. Psychiatric comorbidity and compulsive/impulsive traits in compulsive sexual behavior. Compr. Psychiatry 44, 370-380.

Reinares, M., Sanchez-Moreno, J., Fountoulakis, K.N., 2014. Psychosocial interventions in bipolar disorder: what, for whom, and when. J. Affect. Disord. 156, 46-55.

Rocha, F.L., Rocha, M.E., 1992. Kleptomania, mood disorder and lithium. Arq Neuropsiquiatr. 50, 543-546.

Sapir, R., Zohar, A.H., Bersudsky, Y., Belmaker, R., Osher, Y., 2013. Behavioral addictions in euthymic patients with bipolar I disorder: a comparison to controls. Int. J.Bipolar. Disord. 1 (27).

Scanavino, M.T., Ventuneac, A., Abdo, C.H., Tavares, H., do Amaral, M.L., Messina, B., et al., 2013. Compulsive sexual behav- 
ior and psychopathology among treatment-seeking men in Sao Paulo, Brazil. Psychiatry Res. 209, 518-524.

Singh, J., Mattoo, S.K., Sharan, P., Basu, D., 2005. Quality of life and its correlates in patients with dual diagnosis of bipolar affective disorder and substance dependence. Bipolar. Disord. 7, 187-191.

Soberay, A., Faragher, J.M., Barbash, M., Brookover, A., Grimsley, P., 2014. Pathological gambling, co-occurring disorders, clinical presentation, and treatment outcomes at a university-based counseling clinic. J. Gambl. Stud. 30, 61-69.

Swann, A.C., 2010. The strong relationship between bipolar and substance-use disorder. Ann. N.Y. Acad. Sci 1187, 276293.

Swann, A.C., Dougherty, D.M., Pazzaglia, P.J., Pham, M., Moeller, F.G., 2004. Impulsivity: a link between bipolar disorder and substance abuse. Bipolar. Disord. 6, 204-212.
Vieta, E., Berk, M., Schulze, T.G., Carvalho, A.F., Suppes, T., Calabrese, J.R., et al., 2018a. Bipolar disorders. Nat. Rev. Dis. Primers. 4, 18008.

Vieta, E., Salagre, E., Grande, I., Carvalho, A.F., Fernandes, B.S., Berk, M., et al., 2018b. Early intervention in bipolar disorder. Am. J. Psychiatry appiajp201717090972.

Vieta, E., Salagre, E., Grande, I., Carvalho, A.F., Fernandes, B.S., Berk, M., et al., 2018c. Early intervention in bipolar disorder. Am. J. Psychiatry appiajp201717090972.

Wolfling, K., Beutel, M.E., Dreier, M., Muller, K.W., 2015. Bipolar spectrum disorders in a clinical sample of patients with internet addiction: hidden comorbidity or differential diagnosis? J. Behav. Addict. 4, 101-105.

Zimmerman, M., Chelminski, I., Young, D., 2006. Prevalence and diagnostic correlates of DSM-IV pathological gambling in psychiatric outpatients. J. Gambl. Stud. 22, 255-262. 